\title{
Review on Biomass
}

\section{Torrefaction Process and}

Product Properties and

Design of Moving Bed

Torrefaction System

Model Development

\section{ASABE Annual International Meeting}

Jaya Shankar Tumuluru

Shahab Sokhansanj

Christopher T. Wright

Richard D. Boardman

J. Richard Hess

The INL is a

U.S. Department of Energy

National Laboratory

operated by

Battelle Energy Alliance

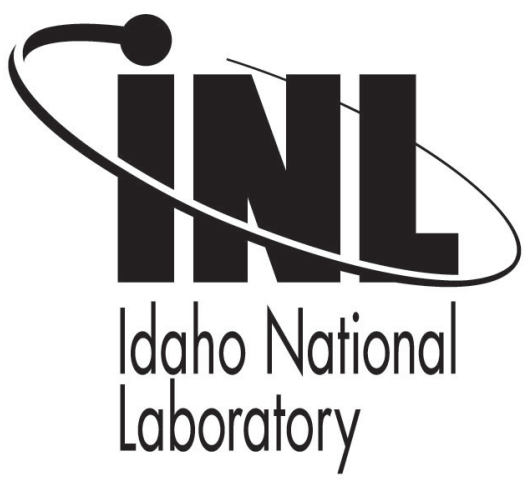

\section{August 2011}

This is a preprint of a paper intended for publication in a journal or proceedings. Since changes may be made before publication, this preprint should not be cited or reproduced without permission of the author. This document was prepared as an account of work sponsored by an agency of the United States Government. Neither the United States Government nor any agency thereof, or any of their employees, makes any warranty, expressed or implied, or assumes any legal liability or responsibility for any third party's use, or the results of such use, of any information, apparatus, product or process disclosed in this report, or represents that its use by such third party would not infringe privately owned rights. The views expressed in this paper are not necessarily those of the United States Government or the sponsoring agency. 


\title{
Review on Biomass Torrefaction Process and Product properties and Design of Moving Bed Torrefaction System Model Development
}

\author{
Jaya Shankar Tumuluru ${ }^{* 1}$, Shahab Sokhansanj ${ }^{2}$, Christopher T. Wright ${ }^{1}$ Richard D. \\ Boardman $^{1}$ and J. Richard Hess ${ }^{1}$ \\ ${ }^{1 *}$ Idaho National Laboratory, 2525 North Fremont Ave., Idaho Falls Idaho 83415. \\ JayaShankar.tumuluru@inl.gov \\ ${ }^{2}$ Oakridge National Laboratory, Environmental Sciences Division, Oak Ridge, TN 37831-6422 \\ Written for presentation at the \\ 2011 ASABE Annual International Meeting \\ Sponsored by ASABE \\ Gault House \\ Louisville, Kentucky \\ August 7 - 10, 2011
}

\begin{abstract}
Biomass Torrefaction is gaining attention as an important preprocessing step to improve the quality of biomass in terms of physical properties and chemical composition. Torrefaction is a slow heating of biomass in an inert or reduced environment to a maximum temperature of approximately $300^{\circ} \mathrm{C}$. Torrefaction can also be defined as a group of products resulting from the partially controlled and isothermal pyrolysis of biomass occurring in a temperature range of $200-280^{\circ} \mathrm{C}$. Thus, the process can be called a mild pyrolysis as it occurs at the lower temperature range of the pyrolysis process. At the end of the torrefaction process, a solid uniform product with lower moisture content and higher energy content than raw biomass is produced. Most of the smoke-producing compounds and other volatiles are removed during torrefaction, which produces a final product that will have a lower mass but a higher heating value.

There is a lack of literature on the design aspects of torrefaction reactor and a design sheet for estimating the dimensions, heat loads, gas flow rates of the torrefier based on capacity. This study includes (a) a detailed review of biomass torrefaction in terms of understanding the process, product properties, off-gas compositions, and methods used, and (b) a methodology for designing a moving bed torrefier, taking into account the basic fundamental heat and mass transfer calculations. Specific objectives include establishing a set of basic calculations for configuring a torrefaction system, like the diameter and height of the moving packed bed for different capacities, and the heat loads and gas flow rates of the system. Develop Excel( worksheet so a user can define design specifications. In this report, 25-1000 kg/hr are used in equations for the design of the torrefier. Examples of calculations and specifications for the torrefier are included and c) identify the established commercial viable technologies for torrefaction process.
\end{abstract}

Key Words: Biomass torrefaction, Biomass thermal treatments, physical, chemical and biochemical compositions, design model of moving bed torrefier. 


\section{Introduction}

The world is currently facing challenges to reduce dependence on fossil fuels and to achieve a sustainable renewable energy supply. Renewable energies represent a diversity of energy sources that can help maintain the equilibrium of different ecosystems. Among the various sources of renewable energy, biomass is increasingly used as it is considered carbon neutral, since the carbon dioxide released is already part of the carbon cycle (Arias et al., 2008). Increasing the utilization of biomass for energy can help reduce the negative $\mathrm{CO}_{2}$ impact on the environment and help meet the targets established in the Kyoto Protocol (UN, 1998). Energy from biomass can be produced from different processes like thermochemical (combustion, gasification, and pyrolysis), biological (anaerobic digestion and fermentation), or chemical (esterification), in which direct combustion can provide a direct near-term energy solution (Arias et al., 2008). Some of the inherent problems with raw biomass materials, like low bulk density, high moisture content, hydrophilic nature, and low calorific value, limit its ease of use (Arias et al., 2008). In fact, due to its low energy density compared to fossil fuels, high volumes of biomass are needed; adding to problems associated with storage, transportation, and feed handling at a cogeneration plant. Furthermore, grinding biomass can be very costly, and in some cases impractical. All of these drawbacks have led to the development of new technologies in order to increase the quality of biomass fuels. The purpose of this work is mainly focused in four areas:

1. Provide an overview of the torrefaction process, literature review on the physical properties of torrefied raw material and torrefaction gas composition and their significance

2. Methods to analyze the torrefaction gas composition

3. Design of a moving bed using basic principles, such as (a) calculation of the height of the torrefier, (b) equations governing the flow of the gases and solids, and (c) effect of physical properties of the raw materials like moisture content and densities.

4. Development of an excel sheet for calculating the length and diameter of the packed moving bed column based on the design considerations.

5. Identify commercial available torrefaction technologies for biomass processing.

\section{Major Components of Biomass}

A summary of the various components of biomass is given in this section to explain the effect of thermal treatment on compositional changes. Figure 1 indicates the various low molecular weight substances and macromolecular weight substances available in biomass (Mohan et al., 2006).

Biomass materials are essentially a composite of carbohydrate polymers with a small amount of inorganic matter and low molecular weight extractable organic constituents. Figure 1 indicates the linage for both the low- and high-molecular weight macromolecular polymers and oligomers and lignins. The micro and macromolecular substances in the biomass change with the biomass type (i.e., woody or herbaceous). Lignin generally range from 18-35 wt\% while cellulosic material typically ranges from 65-75 wt\%. Low molecular weight species, including the inorganic matter, generally equal less than $10 \mathrm{wt} \%$ of the biomass material. Tables 1 and 2 indicate typical lignocellulosic content of some plant materials. 


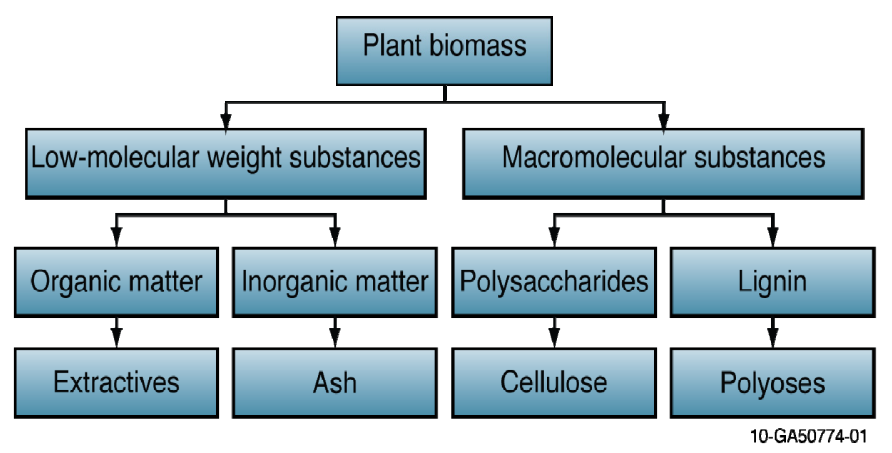

Figure 1. Plant biomass composition (Mohan et al., 2006).

Table 1. Typical lignocellulosic content of some plant materials. (Mohan et al., 2006).

\begin{tabular}{lccc}
\hline & \multicolumn{3}{c}{ Lignocellulosic content (\%) } \\
\cline { 2 - 4 } \multicolumn{1}{c}{ Plant material } & Hemicellulose & Cellulose & Lignin \\
\hline Orchard grass (medium maturity) $^{\mathrm{a}}$ & 40.0 & 32 & 4.7 \\
Rice straw $^{\mathrm{b}}$ & 27.2 & 34.0 & 14.2 \\
Birch wood $^{\mathrm{b}}$ & 25.7 & 40.0 & 15.7 \\
\hline
\end{tabular}

a. Data taken from Van Soest (1964)

b. Data taken from Solo (1965)

Table 2. Hemicellulose, cellulose, and lignin in biomass (daf) (Bridgeman et al., 2008)

\begin{tabular}{lrccc}
\hline & Lignin (\%) & Cellulose (\%) & Hemicellulose (\%) & Total (DMD) \\
\hline Reed canary grass & 7.6 & 42.6 & 29.7 & 80.0 \\
Wheat straw & 7.7 & 41.3 & 30.8 & 79.8 \\
Willow & 20.0 & 49.3 & 14.1 & 83.4 \\
\hline
\end{tabular}

Cellulose is a high molecular weight polymer (with molecular weight up to $10^{6}$ and higher) that makes up the fibers in wood and other biomass. This strength is important in cell walls, where the microfibrils are meshed into a carbohydrate matrix, conferring rigidity to plant cells. Cellulose degradation begins at $240-350^{\circ} \mathrm{C}$, resulting in anhydrous cellulose and levoglucosan (Mohan et al., 2006). The crystalline structure resists thermal depolymerization better than unstructured hemicelluloses. Amorphous regions in the cellulose contain waters of hydration and hold free water within the plant. When heated rapidly, this water is converted to steam which can rupture the cellulose structure.

Unlike cellulose, hemicelluloses are branched polymers (also a polysaccharide) consisting of shorter chains: 500-3000 sugar units as opposed to the 7,000-15,000 glucose molecules per polymer seen in cellulose. It accounts for about 25-35 wt\% in dry wood. Hemicellulose thermal degradation occurs with slow pyrolysis in the range of $130-260^{\circ} \mathrm{C}$, with the majority of weight loss occurring above $180^{\circ} \mathrm{C}$ (Demibras, 2009; Mohan et al., 2006), depending on its chemical nature and relationship with lignin's within the cell. Hemicelluloses generally evolve as light volatiles, producing less tars and char compared to cellulose.

Lignin is an amorphous, highly branched, cross-linked macromolecular polyphenolic resin with no exact structure. Lignin fills the spaces in the cell wall between cellulose, hemicellulose, and pectin components. It is covalently linked to hemicellulose and thereby cross-links different plant polysaccharides, conferring mechanical strength to the cell wall and by extension to the plant as a whole. It is relatively hydrophobic and aromatic in nature. Lignin decomposes when heated to 
$280-500^{\circ} \mathrm{C}$, producing phenols via the cleavage of ether bonds and scissioning of carboncarbon bonds (Demibras, 2009; Mohan et al., 2006). Lignin is difficult to dehydrate and thus converts to more char that cellulose or hemicelluloses.

Organic extractibles include fats, waxes, alkaloids, proteins, phenolics, simple sugars, pectins, mucilages, gums, resins, terpenes, starches, glycosides, saponins, and essential oils (Mohan et al., 2006). Again, these vary in amount and composition depending on the type of biomass. Hence, the devolatilization behavior depends on the amount and the location of the extractibles in the biomass. Figure 2 indicates arrangement of cellulose, hemicellulose, and lignin in a biomass matrix.

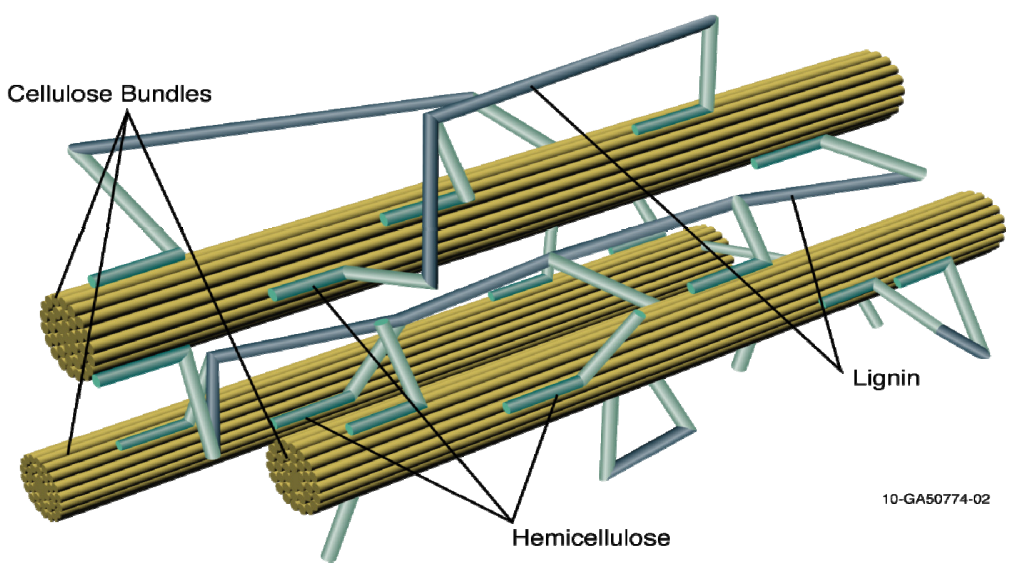

Figure 2. Arrangement of cellulose, hemicellulose, and lignin in biomass matrix (Murphy and McCarthy, 2005; Shaw, 2008).

\section{Torrefaction Overview}

Carbonization of biomass using torrefaction can be good for reducing moisture content and increasing calorific value, which makes biomass energy dense. Torrefaction is a feasible method for improving the properties of biomass as a fuel (Sadaka and Negi, 2009). It consists of heating biomass slowly in an inert atmosphere to a maximum temperature of $300^{\circ} \mathrm{C}$ (Fonseca et al., 1998) and has been defined as the partially controlled and isothermal pyrolysis of biomass occurring in a temperature range of $200-300^{\circ} \mathrm{C}$ (Bergman and Kiel, 2005). The treatment yields a solid uniform product with lower moisture content and higher energy content compared to raw biomass. Torrefaction lowers the $\mathrm{O} / \mathrm{C}$ ratio and makes it more efficient for applications, including gasification and combustion (Bourgois and Doat, 1984; Bourgois and Guyonnet, 1988; Pentananunt et al., 1990; Pach et al., 2002).

The initial heating of biomass during torrefaction removes unbound water. Further heating results in the removal of bound water through chemical reactions. It is assumed that most of the bound water is removed by a thermo-condensation process, which occurs above $160^{\circ} \mathrm{C}$ when the formation of $\mathrm{CO}_{2}$ begins (Zanzi et al., 2002). Further heating between $180-270^{\circ} \mathrm{C}$ results in an exothermic reaction and initiates the decomposition of the hemicellulose, which causes the biomass to change color due to loss of water, $\mathrm{CO}_{2}$, and large amounts of acetic acid and phenols. The energy values of these compounds are relatively low, resulting in a significant increase in the energy density of the biomass (Zanzi et al., 2002). The process becomes completely exothermic at temperatures greater than $280^{\circ} \mathrm{C}$, resulting in significant increases in the production of $\mathrm{CO}_{2}$, phenols, acetic acid, and other higher hydrocarbons (Zanzi et al., 2002). Torrefaction of lignocellulosic materials results in decomposition of more hemicelluloses than lignin and cellulose. These decomposition reactions lead in destruction of hydroxyl groups $(\mathrm{OH})$ 
and further increase the density and specific heating value of the product. The destruction of hydroxyl groups also results in creating a hydrophobic product that remains stable in abusive storage environments, making fungal degradation unlikely (Hakkou et al., 2006). Arias et al., (2008) reported that torrefaction of biomass significantly influences the grindability and reactivity of woody biomass. Bergman et al. (2005a) mentioned that the torrefaction process increases the uniformity of the final product quality. They have found that round wood, demolition wood, and waste wood had similar physical and chemical properties after torrefaction. They also concluded that seasonal influences on these properties were reduced. The torrefaction process, when carried out at temperatures less than $250^{\circ} \mathrm{C}$, is generally endothermic and may decrease its energy efficiency. However, some of the studies carried out on system energy balances and economics indicate that torrefied biomass could be a viable option for co-gasification or cocombustion with coal (Bergman et al., 2005; Prins et al., 2006a; Kavalov and Peteves, 2005). Evaluating the design of torrefaction process for both herbaceous and woody biomass is the purpose of this work.

\section{Principles of Torrefaction}

Torrefaction, also referred to as mild pyrolysis, resides before the pyrolysis process in the continuum of temperatures starting at drying and ending at gasification. Table 3 indicates the typical product yields of wood at different temperature regimes of thermal treatment process (IEA Bioenergy Task 34, 2010).Torrefaction is a process that effectively lowers the O/C ratio of biomass. The energy consumption during milling is reduced, and at the same time sharp edges and splinters are eliminated in the milled powder, greatly enhancing feeding properties. The torrefied biomass has also proved to have hydrophobic properties, which gives an advantage in long term storage compared to raw biomass.

Table 3. Typical product yields (dry wood basis) obtained by different temperature regimes

\begin{tabular}{|c|c|c|c|c|}
\hline Mode & Conditions & $\begin{array}{l}\text { Liquid } \\
\text { (wt \%) }\end{array}$ & $\begin{array}{l}\text { Char } \\
\text { (wt \%) }\end{array}$ & $\begin{array}{l}\text { Gas } \\
\text { (wt } \\
\%)\end{array}$ \\
\hline Fast & $\begin{array}{l}\sim 500^{\circ} \mathrm{C} \text {, short hot vapor residence time } \sim 1 \\
\text { second }\end{array}$ & 75 & 12 & 13 \\
\hline Intermediate & $\begin{array}{l}\sim 500^{\circ} \mathrm{C} \text {, short hot vapor residence time } \sim 10-30 \\
\text { seconds }\end{array}$ & 50 & 25 & 25 \\
\hline $\begin{array}{l}\text { Slow- } \\
\text { Torrefaction }\end{array}$ & $\sim 290^{\circ} \mathrm{C}$, solids residence time $\sim 30 \mathrm{~min}$ & - & $\begin{array}{l}82 \% \\
\text { solid }\end{array}$ & 18 \\
\hline $\begin{array}{l}\text { Slow- } \\
\text { carbonization }\end{array}$ & $\sim 400^{\circ} \mathrm{C}$, long vapor residence time hrs-days & 30 & 35 & 35 \\
\hline Gasification & $\sim 800^{\circ} \mathrm{C}$ & 5 & 10 & 85 \\
\hline
\end{tabular}

\section{Torrefaction Process Technique}

The thermochemical process of torrefaction is actually an incomplete pyrolysis process, and is characterized by the following parameters: reaction temperature $200-300^{\circ} \mathrm{C}$, heating rate < $50^{\circ} \mathrm{C} / \mathrm{min}$, absence of oxygen, residence time $<30$ minutes at $\mathrm{T}>200^{\circ} \mathrm{C}$, ambient pressure, and flexible feedstock. Absence of oxygen in the reactor is of great importance to avoid oxidation and ignition.

Table 4 indicates the various commercially available thermal treatment technologies for drying and torrefaction of biomass. The table includes information on the process used by these companies, configuration which includes whether it is direct heated or indirectly heated, their capacities, present location and their status in terms of operation. 
Table 4. Commercially Available Biomass Thermal Treatment Technologies.

\begin{tabular}{|c|c|c|c|c|c|c|c|c|c|}
\hline Owner & Process & Description & $\begin{array}{l}\text { Heat } \\
\text { Configuration }\end{array}$ & $\begin{array}{l}\text { Product } \\
\text { Name }\end{array}$ & $\begin{array}{l}\text { Operating } \\
\text { Temp }\end{array}$ & $\begin{array}{l}\text { Residence } \\
\text { time }\end{array}$ & Size & Location & Status \\
\hline \multirow[t]{3}{*}{$\begin{array}{l}\text { Alterna } \\
\text { Energy }\end{array}$} & \multirow[t]{3}{*}{$\begin{array}{l}\text { van Aardt } \\
\text { Carbonizing }\end{array}$} & \multirow[t]{3}{*}{$\begin{array}{l}\text { No technology details } \\
\text { provided }\end{array}$} & \multirow[t]{3}{*}{ Unknown } & \multirow[t]{3}{*}{$\begin{array}{l}\text { Biocarbon } \\
\text { pellet }\end{array}$} & $250-300 \mathrm{C}$ & & Research & $\begin{array}{l}\text { B.C } \\
\text { Canada }\end{array}$ & Operating \\
\hline & & & & & $250-300 \mathrm{C}$ & & $25 \mathrm{~K} \mathrm{~T} / \mathrm{yr}$ & $\begin{array}{l}\text { B.C } \\
\text { Canada }\end{array}$ & $2009+$ \\
\hline & & & & & $250-300 \mathrm{C}$ & & small & S. Africa & Operating \\
\hline \multirow[t]{3}{*}{ Dynamotive } & \multirow{3}{*}{$\begin{array}{l}\text { BioTherm Fast } \\
\text { Pyrolysis from } \\
\text { RTI (Resource } \\
\text { Transforms } \\
\text { International) }\end{array}$} & \multirow{3}{*}{$\begin{array}{l}\text { Fluidized bed producing } \\
\text { BioOil and char with } \\
\text { recirculated gases; } \\
\text { requires feed particles with } \\
<10 \% \text { moisture and } 1-2 \mathrm{~mm} \\
\text { size }\end{array}$} & \multirow[t]{3}{*}{ Direct } & \multirow[t]{3}{*}{$\begin{array}{l}\text { BioOil, } \\
\text { BioChar }\end{array}$} & $450-500 \mathrm{C}$ & $2 \mathrm{sec}$ & $15 \mathrm{~T} / \mathrm{d}$ & $\begin{array}{l}\text { Waterloo, } \\
\text { Canada }\end{array}$ & Operating \\
\hline & & & & & $450-500 \mathrm{C}$ & $2 \mathrm{sec}$ & $130 \mathrm{~T} / \mathrm{d}$ & $\begin{array}{l}\text { Ontario, } \\
\text { Canada }\end{array}$ & Operating \\
\hline & & & & & $450-500 \mathrm{C}$ & $2 \mathrm{sec}$ & $200 \mathrm{~T} / \mathrm{d}$ & $\begin{array}{l}\text { Ontario, } \\
\text { Canada }\end{array}$ & Operating \\
\hline \multirow[t]{3}{*}{ ECN } & \multirow{3}{*}{$\begin{array}{l}\mathrm{BO}_{2} \\
\text { Technology or } \\
\text { TOP process }\end{array}$} & \multirow{3}{*}{$\begin{array}{l}\text { Moving bed with } \\
\text { recirculated gas upflow } \\
\text { through biomass downflow }\end{array}$} & \multirow[t]{3}{*}{ Direct } & \multirow[t]{3}{*}{$\mathrm{BO}_{2}$ pellets } & $275-300 \mathrm{C}$ & $30 \mathrm{~min}$ & bench & $\begin{array}{l}\text { ECN } \\
\text { Netherlands }\end{array}$ & Operating \\
\hline & & & & & $275-300 \mathrm{C}$ & $30 \mathrm{~min}$ & $100 \mathrm{~kg} / \mathrm{hr}$ & $\begin{array}{l}\text { ECN } \\
\text { Netherlands }\end{array}$ & Operating \\
\hline & & & & & $275-300 \mathrm{C}$ & $30 \mathrm{~min}$ & $70 \mathrm{~K} \mathrm{~T} / \mathrm{yr}$ & $\begin{array}{l}\text { Delfzijl, } \\
\text { Netherlands }\end{array}$ & $2009+$ \\
\hline EcoFuels & Torrefication & $\begin{array}{l}\text { No technology details } \\
\text { provided }\end{array}$ & Unknown & & $250-300 \mathrm{C}$ & & & & \\
\hline $\begin{array}{l}\text { Heat-Win } \\
\text { Ltd }\end{array}$ & airless drying & $\begin{array}{l}\text { Maintain superheated } \\
\text { steam environment }+ \text { heat } \\
\text { integration }\end{array}$ & Indirect & & $250-300 \mathrm{C}$ & & $10 \mathrm{~T} / \mathrm{hr}$ & Switzerland & $\mathrm{N} / \mathrm{A}$ \\
\hline $\begin{array}{l}\text { NC State } \\
\text { Univ }\end{array}$ & $\begin{array}{l}\text { Continuous } \\
\text { feed drying }\end{array}$ & $\begin{array}{l}\text { Continuous feed drying with } \\
\text { heat integration }\end{array}$ & Indirect & & $300-400 \mathrm{C}$ & & $10 \mathrm{~T} / \mathrm{hr}$ & portable unit & If ordered \\
\hline $\begin{array}{l}\text { NewEarth } \\
\text { Renewable } \\
\text { Energy }\end{array}$ & $\begin{array}{l}\text { ECO Pyro- } \\
\text { Torrefaction }\end{array}$ & $\begin{array}{l}\text { No technology details } \\
\text { provided }\end{array}$ & Unknown & $\begin{array}{l}\text { ECO Clean } \\
\text { Coal } \\
\text { E-Coal, E- } \\
\text { Oil }\end{array}$ & $250+C$ & & $\mathrm{~N} / \mathrm{A}$ & Quebec & Operating \\
\hline $\begin{array}{l}\text { Stramproy } \\
\text { Green }\end{array}$ & $\begin{array}{l}\text { Stramproy } \\
\text { Green }\end{array}$ & $\begin{array}{l}\text { No technology details } \\
\text { provided }\end{array}$ & Direct & biocoal & & & $38 \mathrm{~K} \mathrm{~T} / \mathrm{yr}$ & $\begin{array}{l}\text { Amel, } \\
\text { Belgium }\end{array}$ & $2009+$ \\
\hline \multirow[t]{2}{*}{ Topell } & \multirow[t]{2}{*}{$\begin{array}{l}\text { Torbed } \\
\text { process }\end{array}$} & \multirow[t]{2}{*}{ Cyclone-designed dryer } & \multirow[t]{2}{*}{ Direct } & \multirow[t]{2}{*}{$\begin{array}{l}\text { Torpell } \\
\text { pellets }\end{array}$} & \multirow[t]{2}{*}{$280-320 \mathrm{C}$} & \multirow[t]{2}{*}{$90 \mathrm{sec}$} & Test & $\begin{array}{l}\text { Swidnica, } \\
\text { Poland }\end{array}$ & 2007 \\
\hline & & & & & & & $60 \mathrm{~K} \mathrm{~T} / \mathrm{yr}$ & $\begin{array}{l}\text { Duiven, } \\
\text { Netherlands }\end{array}$ & 2010 \\
\hline Wyssmont & Turbo-dryer & $\begin{array}{l}\text { Rotating/multi-tray dryer } \\
\text { with leveling (uniform } \\
\text { residence time) }\end{array}$ & Direct & & $240-270 \mathrm{C}$ & & pilot plant & $\begin{array}{l}\text { Gramling, S. } \\
\text { Carolina }\end{array}$ & Operating \\
\hline
\end{tabular}




\section{Biomass Reactions}

The cell in woody biomass is a rather complex construction of several building blocks. Polysaccharides are arranged in long chains called microfibrils enclosed in even structures of amorphous lignin and building the core of the crystalline cellulose. The cellulose is encased in a shell of hemicellulose. All these building blocks are more or less influenced by heat, but in different temperature ranges; therefore, they are converted by specific reactions. The physiochemical changes in biomass during torrefaction are shown in Figure 3.

\section{Process Reactions and Results}

Drying: $200^{\circ} \mathrm{C}$

Torrefaction reactions: $200-300^{\circ} \mathrm{C}$

a. Devolatilization and carbonization of hemicellulose

b. Depolymerization and devolatilization/softening of lignin

c. Depolymerization and devolatilization of cellulose.

Mass yield: $\sim 70 \%$

Energy yield: $\sim 90 \%$

Net calorific value: (LHV) 17-19 MJ/kg $\rightarrow$ 18-23 MJ/kg

Moisture content: $1-2 \%$

Hydrophobic, max: 1-6\% moisture uptake.

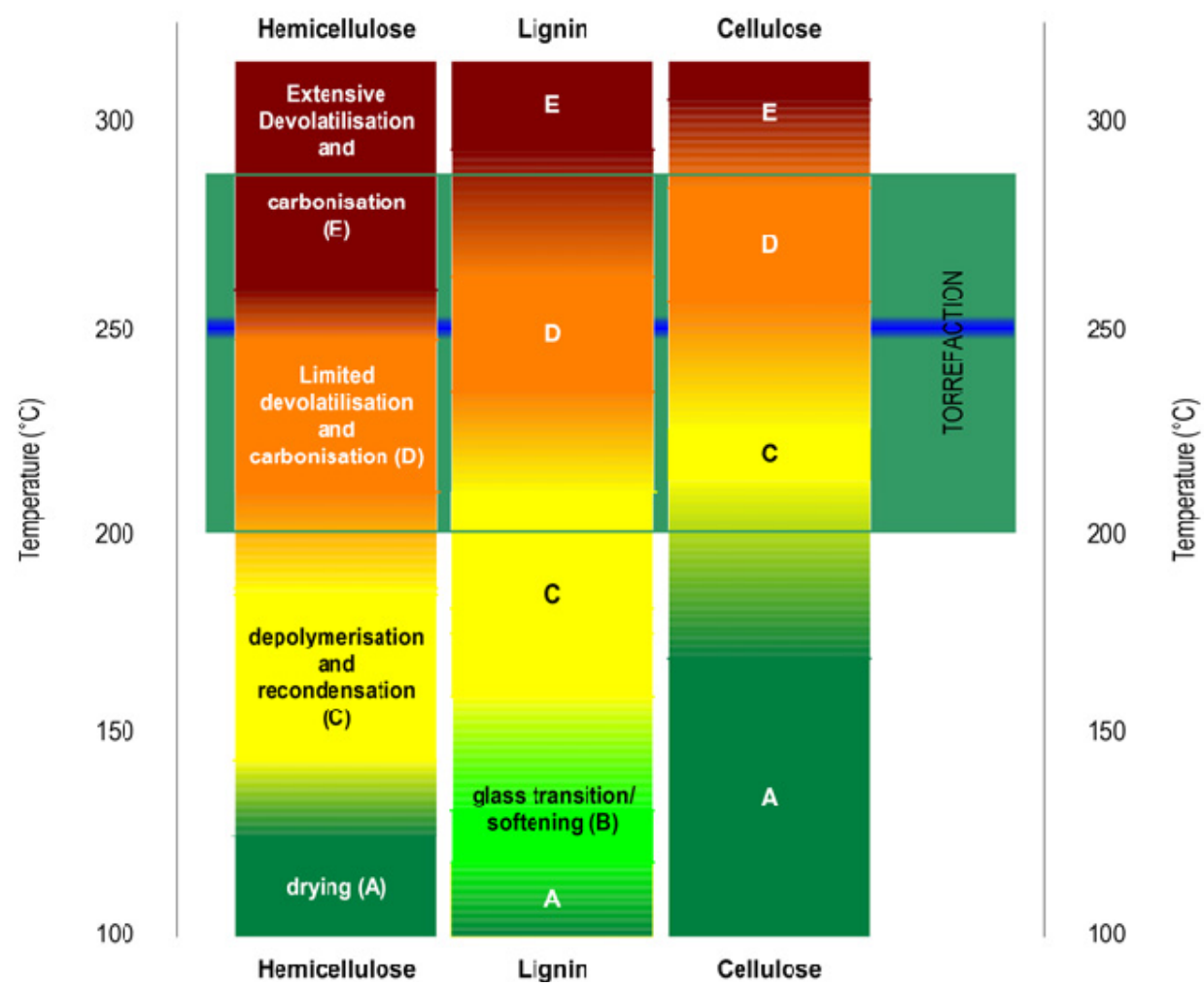

Figure 3. Physiochemical changes in biomass during torrefaction (Bergman et al., 2005a).

\section{Torrefaction Mass and Energy Balance}

A typical mass and energy distribution can be seen in Table 5, which shows the high preservation of mass and energy content in the solid product. Besides the solids, mostly water 
is produced during torrefaction, and the energy content of the volatiles is preserved in the lipids and organics. Torrefaction operating conditions and biomass properties have a significant impact on the amount of both the solid residue remaining and the volatile and gaseous products produced. As a result, for different studies, their analysis results are not exactly the same. Prins et al. (2006) conducted several typical overall mass balances of torrefaction experiments. These data are reproduced in Figure 4 and show that, for different biomass types, their product distributions have big differences. Larch has the largest yield of solid product, and smallest gas and liquid yield; straw has higher gas and liquid fractions than woody biomass; and willow is between woody biomass and straw. It was also found that an increase in torrefaction temperature leads to a decrease in solid biochar yield and an increase in the volatile fractions, including liquid and non-condensable gases. That is a result of the competition between charring and devolatilization reactions that become more reactive at higher temperatures. The study of Deng et al. (2009) on the influence of temperatures on the yields of torrefied samples and heating value can be seen in Table 6. Mani (2009) worked on the effect of torrefaction temperature on the proximate composition of forest residue samples (Table 7).

Table 5. Mass and energy distribution for torrefaction of willow in $280^{\circ} \mathrm{C}$ for 17.5 min reaction time (Bergman and Kiel, 2005). (daf: dry and ash free basis)

\begin{tabular}{crc}
\hline $\begin{array}{c}\text { Reaction } \\
\text { products }\end{array}$ & Mass yield & Energy yield (LHV, daf) (\%) \\
\hline Solid & 87.5 & 94.9 \\
Lipids & 1.40 & 3.40 \\
Organics & 1.70 & 1.60 \\
Gases & 1.40 & 0.10 \\
Water & 8.00 & 0.00 \\
\hline
\end{tabular}

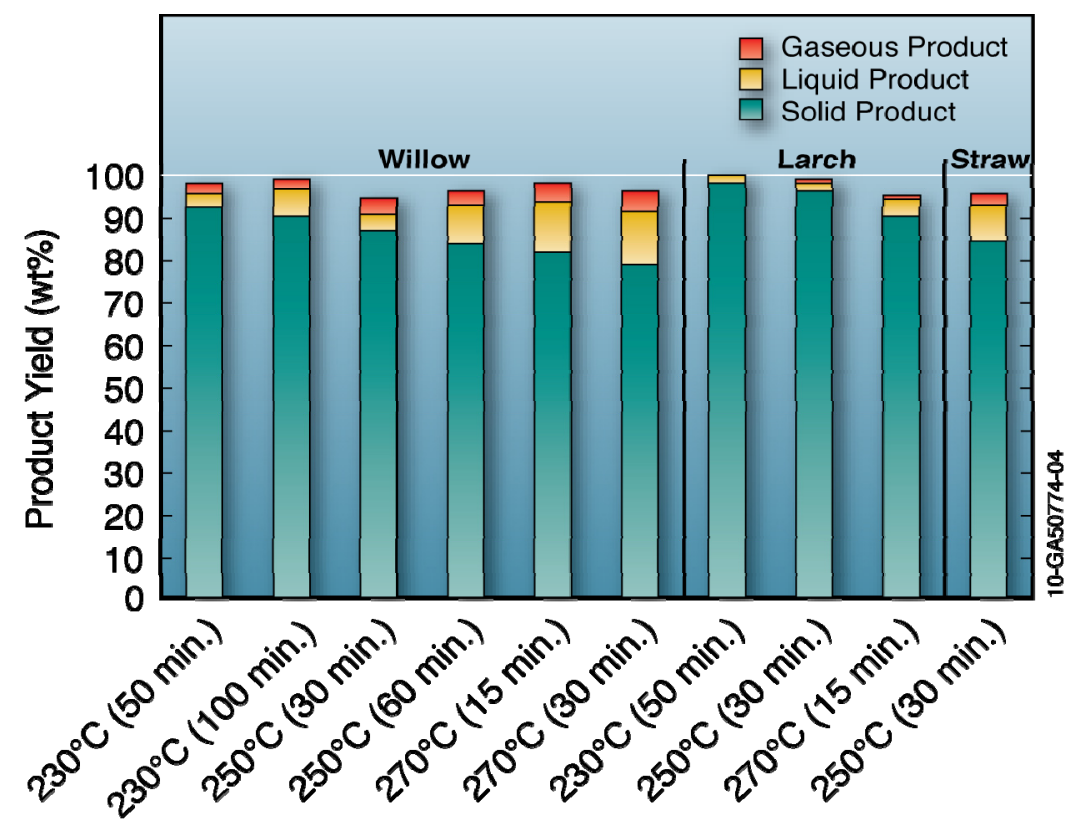

Figure 4. Overall mass balance of several torrefaction experiments. 
Table 6. Influence of temperatures on samples yields and heating value (Deng et al., 2009).

\begin{tabular}{lcccccc}
\hline Samples & $\begin{array}{c}\text { Temperature } \\
\left({ }^{\circ} \mathrm{C}\right)\end{array}$ & $\begin{array}{c}\text { Solids } \\
(\text { wt, \%) }\end{array}$ & $\begin{array}{c}\text { Liquids } \\
(\text { wt, \%) }\end{array}$ & $\begin{array}{c}\text { Gases } \\
(\text { wt, \%) }\end{array}$ & $\begin{array}{c}\text { Conversion } \\
(\text { wt, \%) }\end{array}$ & $\begin{array}{c}\text { HHV } \\
(\mathrm{MJ} / \mathrm{kg})\end{array}$ \\
\hline Rice straw & 200 & 59.84 & 3.47 & 36.69 & 40.16 & 17.16 \\
& 250 & 40.32 & 4.23 & 55.45 & 59.68 & 18.03 \\
& 300 & 36.57 & 6.56 & 56.87 & 63.43 & 18.68 \\
Rape & 200 & 63.29 & 6.76 & 29.95 & 36.71 & 19.50 \\
stalk & & & & & & \\
& 250 & 38.26 & 9.42 & 52.32 & 61.74 & 20.10 \\
& 300 & 25.30 & 10.04 & 64.66 & 74.70 & 21.59 \\
\hline
\end{tabular}

Table 7. Proximate analysis of torrefied forest residue samples (Mani, 2009).

\begin{tabular}{llllll}
$\begin{array}{l}\text { Torrefaction } \\
\text { temperature } \\
\left({ }^{\circ} \mathrm{C}\right)\end{array}$ & $\begin{array}{l}\text { Moisture } \\
\text { content }(\%)\end{array}$ & $\begin{array}{l}\text { Volatiles } \\
(\text { wt, \%) }\end{array}$ & $\begin{array}{l}\text { Fixed Carbon } \\
(\text { wt, \%) }\end{array}$ & $\begin{array}{l}\text { Heating value } \\
(\mathrm{Btu} / \mathrm{lb})\end{array}$ & Ash $(\%)$ \\
\hline Non-torrefied & 10 & 75.3 & 16.3 & 7,774 & 0.67 \\
220 & 3.2 & 76.8 & 19.1 & 8,474 & 1.1 \\
250 & 2.3 & 74.9 & 20.6 & 9,376 & 1.2 \\
280 & 2.1 & 70.8 & 25.6 & 10,167 & 1.4 \\
\hline
\end{tabular}

Comparing the conversion of agricultural residues (rice straw and rape stalk) to woody biomass from literatures, the conversion of the former is much higher than that of the latter under the same torrefaction conditions (temperature and residence time) (Bergman et al., 2005). This is due to the higher volatile matter content in the agricultural residues and the decomposition of hemicellulose, the main fraction decomposed in the temperature range of torrefaction. Bridgeman et al. (2008) drew similar conclusions that the mass yield (dry ash free) was 55.1\%, $61.5 \%$, and $72.0 \%$ for wheat straw, reed canary grass, and willow, respectively, at $290^{\circ} \mathrm{C}$ for 30 minutes. Bridgeman et al. (2008) have listed the energy and mass yields, and volatiles lost during torrefaction of reed canary grass, wheat straw, and willow at different temperatures (Table 8). Table 9 show the solid liquid and gases distribution during torrefaction of willow at $280^{\circ} \mathrm{C}, 17.5$ minutes.

Table 8. Energy and mass yields, and volatiles lost during torrefaction of reed canary grass, wheat straw, and willow at different temperatures (Bridgeman et al., 2008).

\begin{tabular}{lrrrc}
\hline \multicolumn{5}{c}{ Temperature $\left({ }^{\circ} \mathrm{K}\right)$} \\
\hline & 503 & 523 & 543 & 563 \\
\hline Reed Canary Grass & & & 72.0 & 61.5 \\
\hline Mass yield (daf) & 92.6 & 84.0 & 77.1 & 69.0 \\
Energy yield (daf) & 93.5 & 86.6 & 28.0 & 38.5 \\
Volatiles (daf) & 7.4 & 16.0 & & \\
\hline Wheat Straw & & & 71.5 & 55.1 \\
\hline Mass yield (daf) & 91.0 & 82.6 & 78.2 & 65.8 \\
Energy yield (daf) & 93.5 & 86.2 & & \\
\hline
\end{tabular}




\begin{tabular}{lrccl}
\hline Volatiles (daf) & 9.0 & 17.4 & 28.5 & 44.9 \\
\hline Willow & & & & \\
\hline Mass yield (daf) & 95.1 & 89.6 & 79.8 & 72.0 \\
Energy yield (daf) & 96.5 & 92.7 & 85.8 & 79.2 \\
Volatiles (daf) & 4.9 & 10.4 & 20.2 & 28 \\
\hline Note: daf: dry ash free basis & & & & \\
\hline
\end{tabular}

Table 9. Mass distribution for torrefaction of willow at $280^{\circ} \mathrm{C}$ for 17.5 minutes.

\begin{tabular}{lc}
\hline \multicolumn{1}{c}{ Reaction products } & Mass yield (\%) \\
\hline Solids & 87.7 \\
Lipids (Terpenes, phenols, fatty acids, waxes, and tannins) & 1.40 \\
Organics (Sugars, polysuguars, acids, alcohols, furans, and & 1.70 \\
ketones) & \\
Gases $\left(\mathrm{H}_{2}, \mathrm{CO}, \mathrm{CO}_{2}, \mathrm{CH}_{4}, \mathrm{C}_{\mathrm{x}} \mathrm{H}_{\mathrm{y}}\right.$, toluene, and benzene) & 1.40 \\
Water & 8.00 \\
\hline \multicolumn{2}{l}{ Source: Bergman and Kiel (2005); Bergman et al. (2005). } \\
\hline
\end{tabular}

\section{Torrefaction Products}

During the torrefaction of biomass, three primary products are produced: a) solid product of a brown/dark color; b) condensable liquid including mostly moisture, acetic acid and other oxygenates; and c) non-condensable gases-mainly $\mathrm{CO}_{2}, \mathrm{CO}$, and small amounts of methane. The last two products can be represented by volatiles. During torrefaction the raw material loses most of its moisture and other volatiles which have a low heat value. Many researchers have worked on identifying the gas composition in terms of quantity and quality. The type and amount of the gas that comes as off-gas during torrefaction depends upon the raw material type and torrefaction process conditions, including the process temperature and residence time.

Numerous reaction products are formed during torrefaction. Their yield strongly depends on process conditions (temperature and time) and on biomass properties. Figure 5 (Bergman et al., 2005) gives an overview of the torrefaction products, classified based on their state at room temperature, which can be solid, liquid, or gas. The solid phase consists of a chaotic structure of the original sugar structures and reaction products. The gas phase includes the gases that are considered permanent gases, but also light aromatic components such as benzene and toluene. The condensables, or liquids, can be divided into three subgroups which include water, organics, and lipids (Figure 5). One subgroup is reaction water as a product from thermal decomposition. The liquid also contains the free and bound water that has been released from the biomass by evaporation. The organics subgroup (in liquid form) consists of organics that are mainly produced during devolatilization and carbonization. Finally, the lipids are a group of compounds that are present in the original biomass. This subgroup contains compounds such as waxes and fatty acids. 


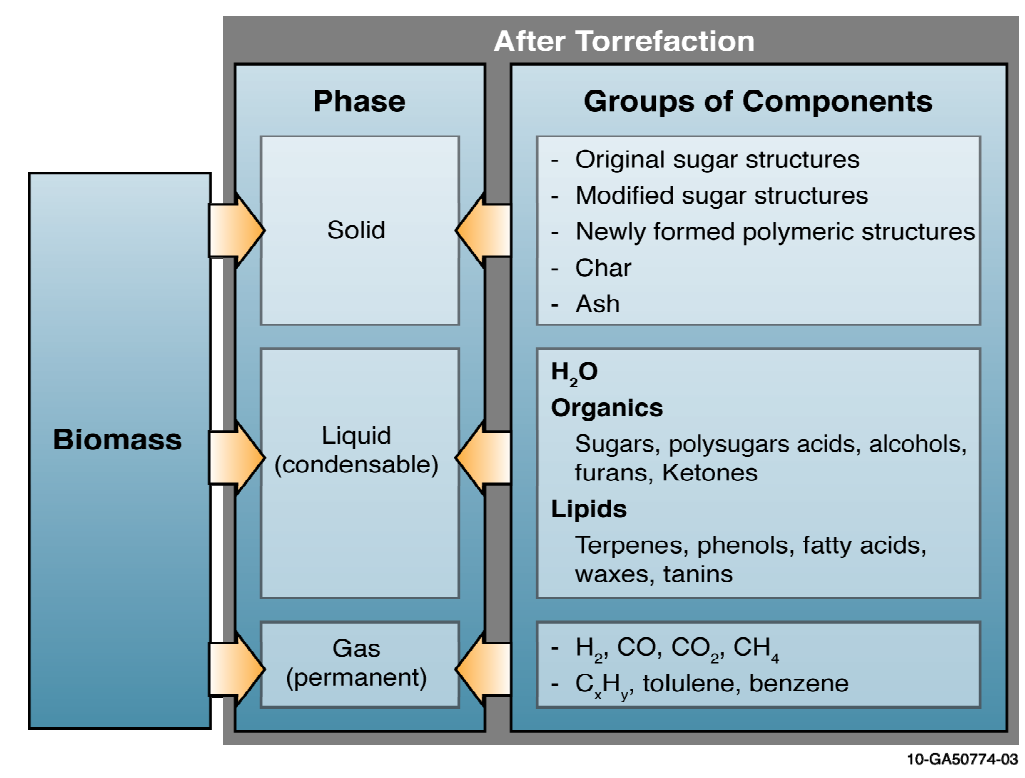

Figure 5. Products formed during torrefaction of biomass (Bergman et al. 2005).

\section{Physical properties and chemical composition of Torrefied Biomass}

Torrefaction of biomass significantly changes physical properties like moisture content, density, grindability, pelletability, hydrophobicity, and calorific value, (Sadaka and Negi, 2009) and also the chemical composition in terms of carbon, hydrogen, oxygen, nitrogen and sulphur.

\section{Moisture Content}

Being a deep drying process, torrefaction reduces the moisture content of the pre-dried biomass from $10 \%$ to $<6 \%$ (Lipinsky et al., 2002). Typically the moisture content of the torrefied biomass ranges between $1-6 \%$ on a weight basis, depending on the conditions of torrefaction (Bergman and Kiel, 2005).

\section{Density}

Mass loss in the form of solids, liquids, and gases during the torrefaction process causes the biomass to become more porous. This results in a significant reduction in volumetric density, typically between $180-300 \mathrm{~kg} / \mathrm{m}^{3}$, depending on initial biomass density and torrefaction conditions (Bergman and Kiel, 2005). Oliveira et al. (2009), in their studies on the effect of torrefaction on energy properties of Eucalyptus grandis wood, indicated that there is a loss of $14.12 \%$ of bulk density when it is torrefied at $280^{\circ} \mathrm{C}$ for 30 minutes. Table 10 indicates the loss of bulk density at torrefaction temperatures ranging $220-280^{\circ} \mathrm{C}$.

Table 10. Bulk density (dry basis) of Eucalyptus grandis wood in three different treatments.

\begin{tabular}{lll}
\hline Treatment & Bulk density $\left(\mathrm{g} / \mathrm{cm}^{3}\right)$ & Percentage loss \\
\hline Control $^{*}$ & $0.85^{\mathrm{a}}$ & - \\
$\mathrm{T} 2-220^{\circ} \mathrm{C}$ & $0.83^{\mathrm{a}}$ & 2.35 \\
$\mathrm{~T} 3-250^{\circ} \mathrm{C}$ & $0.79^{\mathrm{b}}$ & 7.06 \\
$\mathrm{~T} 4-280^{\circ} \mathrm{C}$ & $0.73^{\mathrm{c}}$ & 14.12 \\
\hline
\end{tabular}

Note: Means followed by the same letter in the superscript are statistically similar at the $5 \%$ probability level. * Average moisture content of control treatment $=15 \%$ 


\section{Grindability}

Biomass is highly fibrous and tenacious in nature, because fibers form links between particles and make the handling of the raw ground samples difficult. During the torrefaction process the biomass loses its tenacious nature, which is mainly coupled to the breakdown of the hemicellulose matrix and depolymerization of the cellulose, resulting in the decrease of fiber length (Bergman et al., 2005; Bergman and Kiel, 2005). There is a significant decrease in the particle length but not the diameter per se, resulting in better grindability, handling characteristics, and the ability of the biomass to flow unhindered through processing and transportation systems. During the torrefaction process the biomass tends to shrink; becomes lightweight, flaky, and fragile; and loses its mechanical strength, making it easier to grind and pulverize (Arias et al., 2008). Bergman and Kiel (2005) conducted studies on the energy requirements for grinding raw and torrefied biomass like willow, woodcuttings, demolition wood, and coal using a heavy duty cutting mill. They concluded that power consumption reduces dramatically when biomass is first torrefied. The reduction in power consumption ranges from $70-90 \%$, based on the conditions under which the material is torrefied. They have also found that the capacity of the mill increases by a factor 7.5-15. The most important phenomenon they have observed was that the size reduction characteristics of torrefied biomass resulted in a great similarity with coal.

\section{Particle size distribution, sphericity, and particle surface area}

Particle size distribution curves, sphericity, and surface area are important parameters for understanding flowability and combustion behavior during cofiring. Many researchers observed that ground, torrefied biomass produced narrower, more uniform particle sizes compared to untreated biomass due to its brittle nature, which is similar to coal. Phanphanich and Mani (2011) study on torrefied pine chips and logging residues found that smaller particle sizes are produced compared to untreated biomass. They have also observed that the particle distribution curve was skewed towards smaller particle sizes with increased torrefaction temperatures.

Torrefaction also significantly influences the sphericity and particle surface area. Phanphanich and Mani (2011) results also indicated that sphericity and particle surface area increases as the torrefaction temperature was increased up to $300^{\circ} \mathrm{C}$. For ground, torrefied chips, they found that the sphericity increased from $0.48-0.62 \%$, concluding that an increase in particle surface area or decrease in particle size of torrefied biomass can be desirable properties for efficient cofiring and combustion applications. Also, the bulk and particle densities of ground torrefied biomass increases as it reduces the inter and intra particle voids generated after milling (Mani et al., 2004; Esteban and Carrasco, 2006). Research studies have indicated that ground torrefied material results in a powder with a favorable size distribution and spherical particles, allowing torrefied powder to meet the smooth fluidization regime required for feeding it to entrained-flow processes (gasifier and pulverized coal).

\section{Pelletability}

Variability in feed stock quality due to differences in the types of raw materials, tree species, climatic and seasonal variations, storage conditions, and time significantly influence the quality of biopellets (Lehtikangas, 1999). On the other hand, torrefying the biomass before pelletization produces uniform feedstock with consistent quality. Lignin in the biomass is considered as the basic binding agent; thus the pelletability of any biomass is evaluated based on the amount of the lignin. In general, the higher the amount of lignin, the better the binding and milder the process conditions required for densification. Woody biomass has more lignin than lignocellulosic biomass and binds easily. Torrefaction process opens up more lignin active sites by breaking down the hemicellulose matrix and forming fatty unsaturated structures which 
creates better binding. The bulk densities of the torrefied pellets are $750-850 \mathrm{~kg} / \mathrm{m}^{3}$ (Bergman and Kiel, 2005).

Densification following torrefaction is considered by several researchers (Lipinsky et al., 2002; Reed and Bryant, 1978; Koukios, 1993; Bergman et al., 2005). These studies indicated that the pressure required for densification can be reduced by a factor of two when material is densified at a temperature of $225^{\circ} \mathrm{C}$ and the energy consumption during densification is reduced by a factor of two compared to raw biomass pelletization using a pellet mill. Densification experiments were carried out on untreated and torrefied biomass using a piston press (ProntoPress), which can be operated at different pressures and temperatures, to understand the densification behavior of different types of torrefied biomass. The pellets produced based on the TOP process had higher bulk densities, in the range of $750-850 \mathrm{~kg} / \mathrm{m}^{3}$, with the relatively highcalorific value (LHV basis) of torrefied biomass (generally 19-22 MJ/kg). The energy density of TOP pellets ranged from $15-18.5 \mathrm{GJ} / \mathrm{m}^{3}$ and is comparable to subbituminous coal, which typically has a value of $21-22 \mathrm{GJ} / \mathrm{m}^{3}$. The pellets produced had a higher mechanical strength, typically 1.5-2 times greater, than the conventional pellets. The higher mechanical strength of these pellets is due to densification of the biomass at high temperature, which causes the biomass polymers to be in a weakened state (less fibrous, more plastic). The higher durable pellets from torrefied biomass can be due to chemical modifications that occur during torrefaction lead to more fatty structures that act as binding agent. In addition, the lignin content increases by $10-15 \%$, as the devolatilization process predominantly concerns hemicellulose (Bergman, 2005). Figure 6 shows the flow diagram for the torrefaction and pelletization (TOP) process that Bergman (2005) proposed.

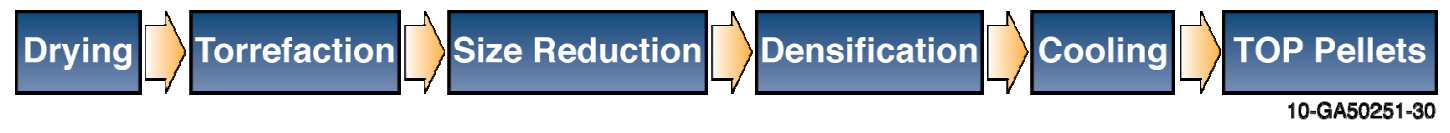

Figure 6. Flow diagram for production of torrefied wood pellets.

\section{Chemical composition of the torrefied biomass}

Besides improving physical attributes, torrefaction also results in significant changes in proximate and ultimate composition of the biomass and makes it more suitable for fuel applications. Sadaka and Negi's (2009) study on torrefaction of wheat straw, rice straw, and cotton gin waste at 200,260 , and $315^{\circ} \mathrm{C}$ for 60,120 , and 180 minutes has concluded that moisture content was reduced at the extreme conditions $\left(315^{\circ} \mathrm{C}\right.$ for 180$)$ for all three feedstocks by $70.5,49.4$, and $48.6 \%$, and the heating value increased by $15.3,16.9$, and $6.3 \%$, respectively. Zanzi et al. (2002), in their study on miscanthus torrefaction made similar observations, where increasing temperature from $230-280^{\circ} \mathrm{C}$ and time from $1-3$ hours increased the carbon content and decreased the hydrogen, nitrogen, and oxygen content. At $280^{\circ} \mathrm{C}$, the carbon content increased to about $52 \%$ from an initial value of $43.5 \%$ while hydrogen and nitrogen content decreased from $6.49-5.54 \%$ and $0.90-0.65 \%$ for 2 hours of torrefaction. In general, increased torrefaction temperatures result in increased carbon content and decreased hydrogen and oxygen content due to the formation of water, $\mathrm{CO}$, and $\mathrm{CO}_{2}$.

This process also causes the hydrogen-to-carbon $(\mathrm{H} / \mathrm{C})$ and oxygen-to-carbon $(\mathrm{O} / \mathrm{C})$ ratios to decrease with increasing torrefaction temperature and time, which results in less smoke and water-vapor formation and reduced energy loss during combustion and gasification processes. In torrefaction studies of reed canary grass and wheat straw torrefaction at 230, 250, 270, and $290^{\circ} \mathrm{C}$ for 30-minute residence times, Bridgeman et al. (2008) found that the moisture content decreases from an initial value of $4.7 \%-0.8 \%$. They found that carbon increased $48.6-54.3 \%$, 
and hydrogen and nitrogen content decreased from $6.8-6.1 \%$ and $0.3-0.1 \%$, respectively. Bridgeman et al. (2010) gave a Van Krevelen diagram for torrefied willow and miscanthus (Figure 7). It is clear that at higher temperatures and residence times, the atomic $\mathrm{O}: \mathrm{C}$ and $\mathrm{H}: \mathrm{C}$ ratios are closer to that of lignite coal. Table 6 shows the effect of different torrefaction temperatures on ultimate compositional changes in woody and herbaceous biomass. Table 11 and 12 indicates the elemental composition of the torrefied biomass at different temperatures and times.

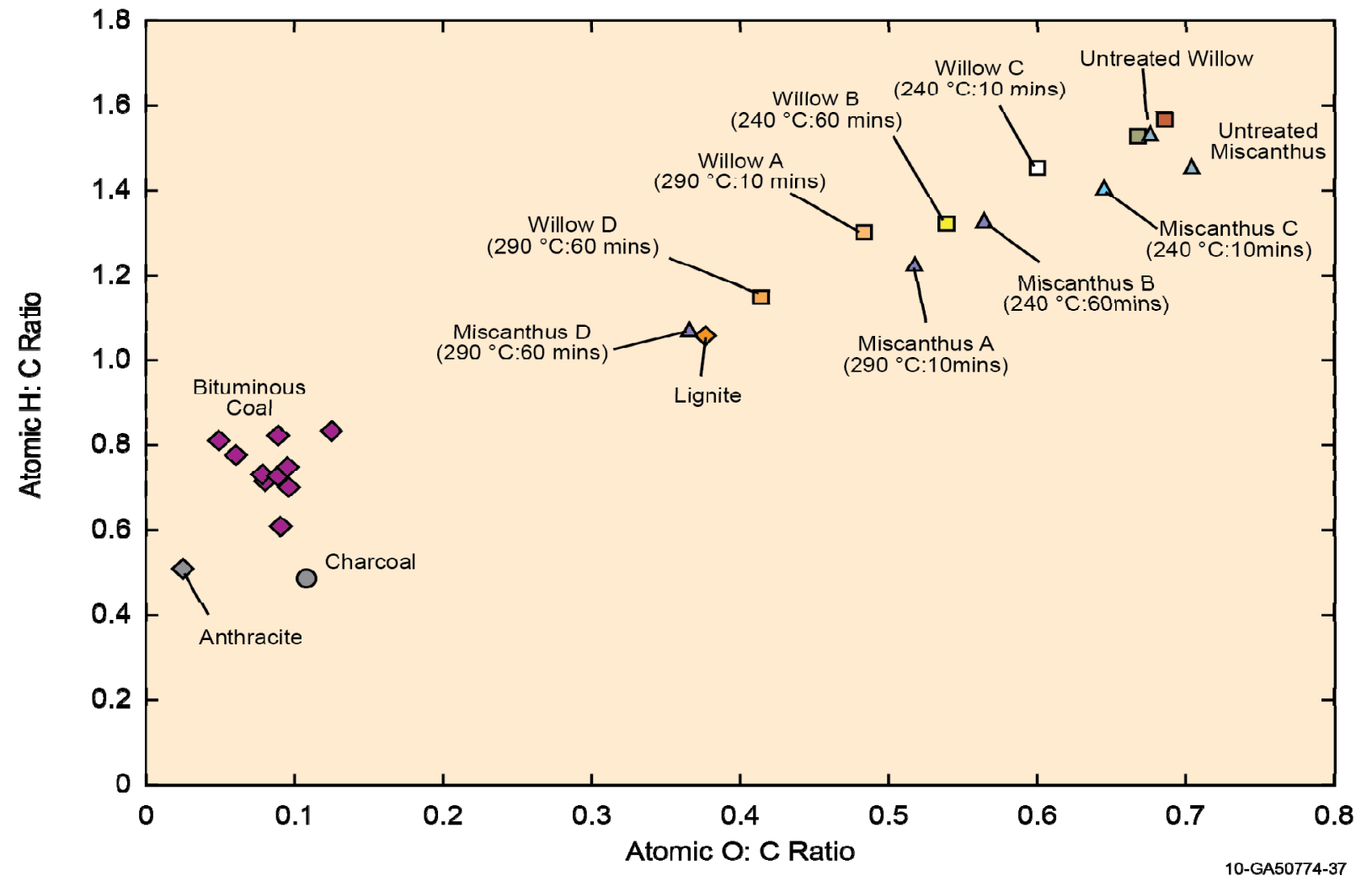

Figure 7. Van Krevelen diagram for torrefied willow and miscanthus Bridgeman et al. (2010).

Table 11. Elemental compositions of solid products.

\begin{tabular}{|c|c|c|c|c|c|c|}
\hline & Temperature $\left({ }^{\circ} \mathrm{C}\right)$ & Time (h) & C & $\mathrm{H}$ & $\mathrm{N}$ & $\mathrm{O}$ \\
\hline & & & \multicolumn{4}{|c|}{ Moisture and ash free (wt, \%) } \\
\hline Birch & \multicolumn{2}{|l|}{ Raw } & 47.40 & 6.11 & 0.16 & 46.33 \\
\hline & 230 & 1 & 48.20 & 5.93 & 0.16 & 45.71 \\
\hline & 230 & 2 & 48.72 & 5.88 & 0.14 & 45.26 \\
\hline & 230 & 3 & 48.82 & 5.76 & 0.13 & 45.29 \\
\hline & 250 & 1 & 49.50 & 5.69 & 0.13 & 44.68 \\
\hline & 250 & 2 & 49.86 & 5.68 & 0.12 & 44.34 \\
\hline & 250 & 3 & 50.05 & 5.65 & 0.12 & 44.18 \\
\hline & 280 & 1 & 51.25 & 5.63 & 0.11 & 43.01 \\
\hline & 280 & 2 & 52.00 & 5.62 & 0.11 & 42.27 \\
\hline & 280 & 3 & 52.50 & 5.62 & 0.11 & 41.77 \\
\hline
\end{tabular}

Source: Zanzi et al. (2002). 
Table 12. Ultimate analysis of biomass solid.

\begin{tabular}{lcccccc}
\hline \multicolumn{1}{c}{ Biomass solid } & Temperature $\left({ }^{\circ} \mathrm{C}\right)$ & $\mathrm{C}$ & $\mathrm{H}$ & $\mathrm{N}$ & $\mathrm{S}$ & $\mathrm{O}$ \\
\hline Loblolly Pine & $\mathrm{n} / \mathrm{a}$ & 50.25 & 5.97 & 0 & 0 & 43.34 \\
Wet torrefied loblolly & 200 & 54.72 & 6.03 & 0.14 & 0 & 39.11 \\
pine & 230 & 56.05 & 5.94 & 0.09 & 0 & 37.92 \\
& 260 & 72.07 & 4.90 & 0.16 & 0 & 22.89 \\
\cline { 1 - 5 } Source: Yan et al. (2010). & & & & & & \\
\hline
\end{tabular}

\section{Condensable and non-condensable products produced during torrefaction}

\section{Condensable products}

Water is the major condensable product. Water is released during drying when moisture evaporates and during dehydration reactions between organic molecules. Acetic acid is also a condensable torrefaction product, mainly originating from acetoxy- and methoxy-groups present as side chains in xylose units present in the hemicelluloses fraction. Prins et al. (2006) showed that smaller quantities of formic acid, lactic acid, furfural, hydroxyl acetone, and traces of phenol are also present in the volatile component liberated during the decomposition of biomass. For most of the condensable volatiles, their yields will increase with the torrefaction temperature, as shown in Figure 8. As a result, more energy is transferred to the volatiles fraction in the form of combustibles such as methanol and acetic acid. Bergman et al. (2005) showed the specific energy composition of organics in Figure 9. This figure shows the role of compositions in the energy content of volatiles.

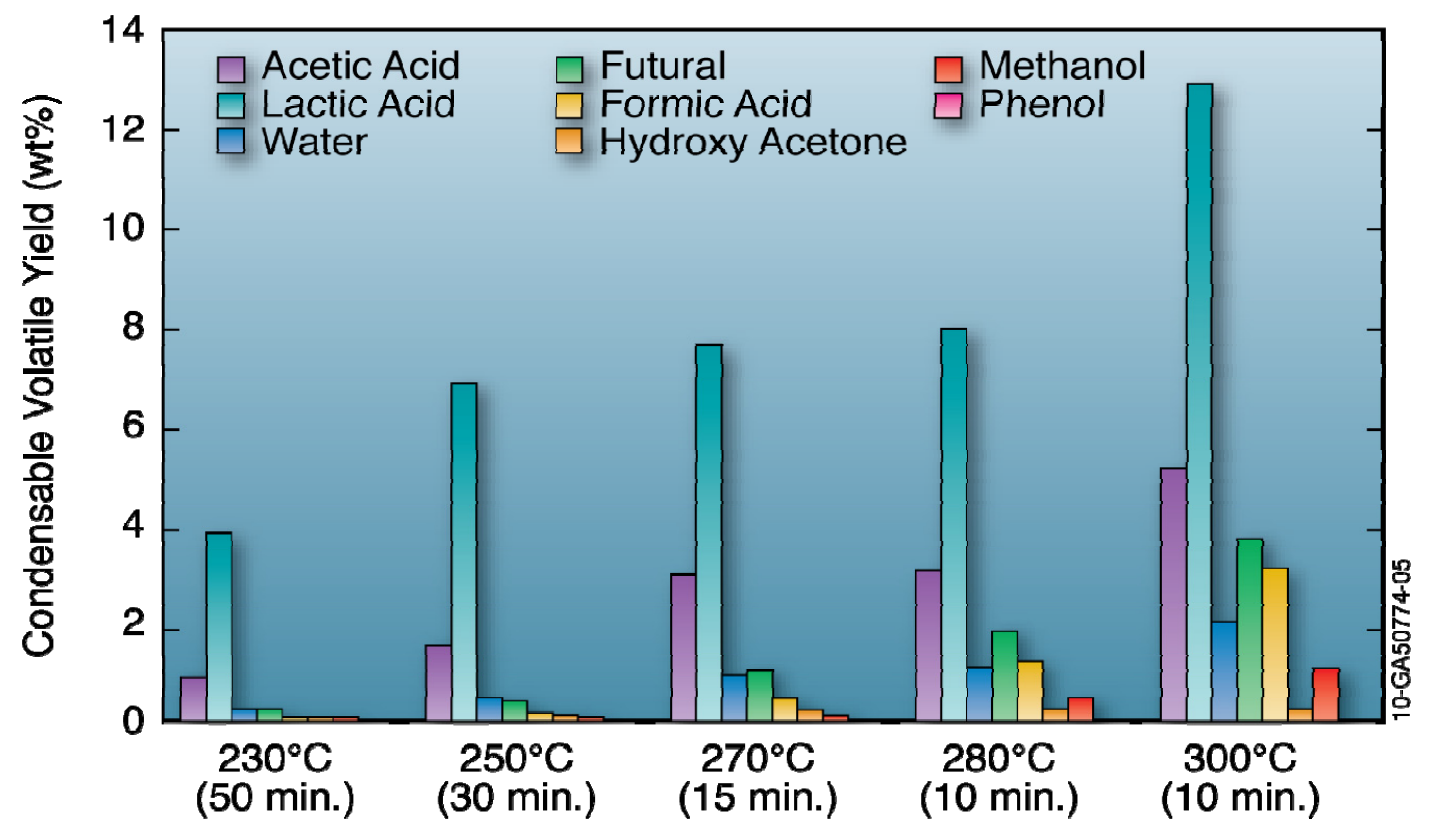

Figure 8. Product yields of condensable volatiles formed in torrefaction (Prins et al. 2006a). 


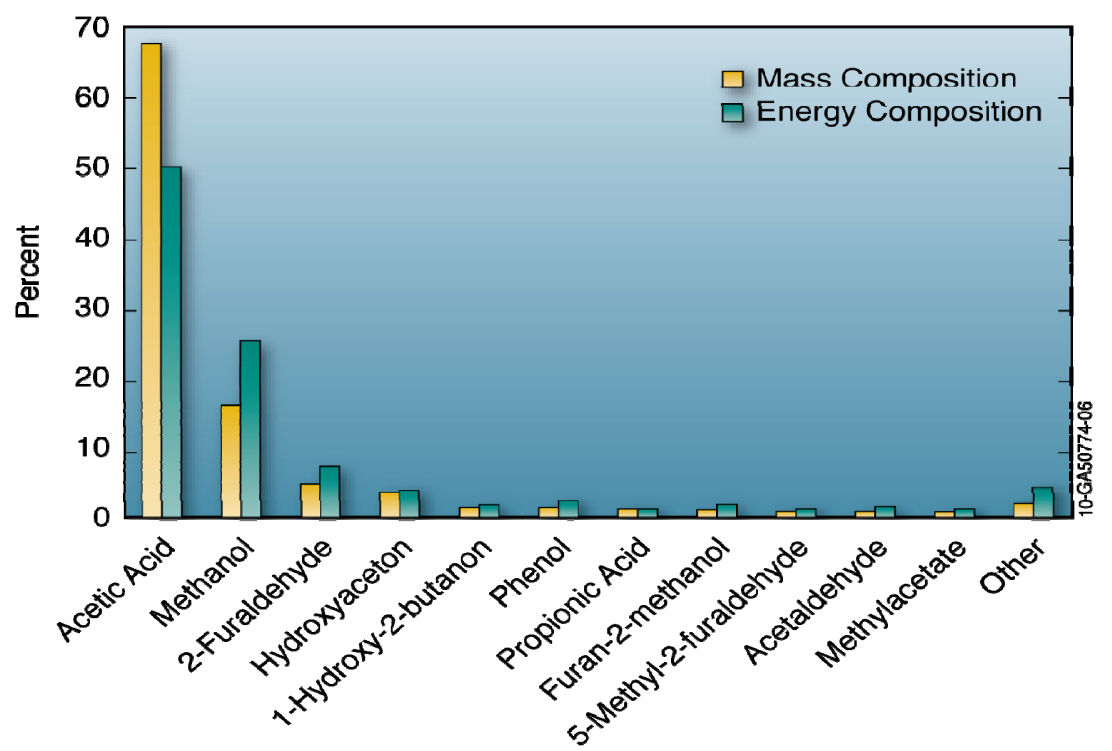

Figure 9. Compositions of the different organic product groups (Kiel, 2007).

\section{Non-condensable products}

The major gases formed in torrefaction are carbon dioxide and carbon monoxide, with only traces of other gases, as shown in Figure 10 (Bergman et al., 2005). Carbon monoxide (CO) is the main source of calorific value of the non-condensable torrefaction products.

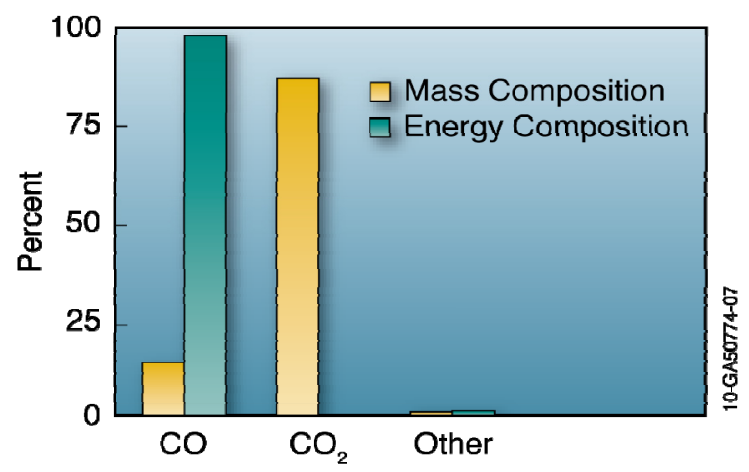

Figure 10. Compositions of the main permanent gases product groups (Kiel ,2007).

The formation of $\mathrm{CO}_{2}$ may be explained by decarboxylation of acid groups in the wood. The formation of $\mathrm{CO}$ cannot be explained by dehydration or decarboxylation reactions. The increased CO formation is reported in literature (White and Dietenberger, 2001) as the reaction of carbon dioxide and steam with porous char. This reaction produces CO. Traces of hydrogen and methane are also detected in non-condensable products. A gas composition comparison between wood and agricultural residues indicates that the latter is characterized by a higher $\mathrm{CO}_{2}$ production (Bergman et al., 2005; Prins et al., 2006; Deng et al., 2009). In addition, a kinetic study on the generation of main non-condensable gases shows that the gases are formed through parallel independent first-order reactions (Prins et al., 2006). The composition of the non-condensable volatile product obtained from torrefaction at different conditions is depicted in Figure 11, with more $\mathrm{CO}_{2}$ than $\mathrm{CO}$. The ratio of $\mathrm{CO}$ to $\mathrm{CO}_{2}$ increased with temperature because cellulose and lignin decompose at higher temperatures (Prins et al., 2006). Figure 12 shows the gas composition of the non-condensable products over time (not 
totaling exactly to $100 \%$ because only the main components, $\mathrm{CO}_{2}$ and $\mathrm{CO}$, are shown) (Prins et al., 2006). These results were obtained by torrefaction of larch and willow at $250^{\circ} \mathrm{C}$ and analysis of non-condensable gases after 5,15 , and 30 minutes. It was found that the ratio of $\mathrm{CO}_{2}$ to $\mathrm{CO}$ decreases with time, in line with the theory that $\mathrm{CO}$ is formed in a secondary reaction. Tables 13 and 14 show the gas composition of the off-gases during torrrefaction of Birch and Willow.

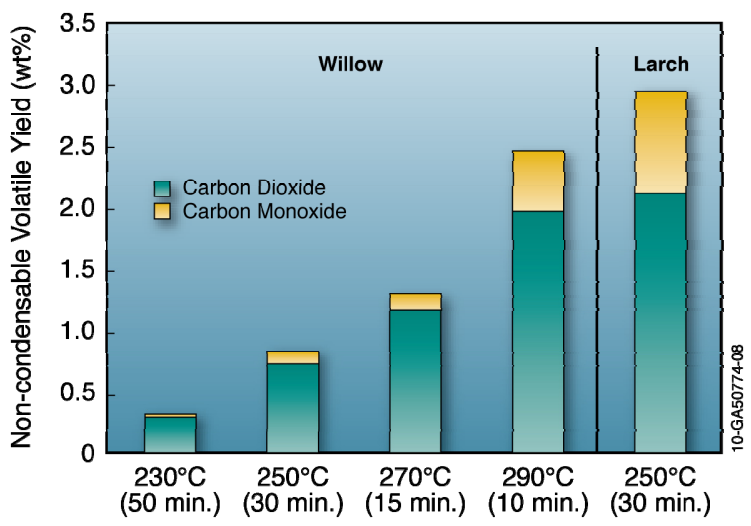

Figure 11. Non-condensable volatiles formed during torrefaction of willow and larch (Prins, 2005).

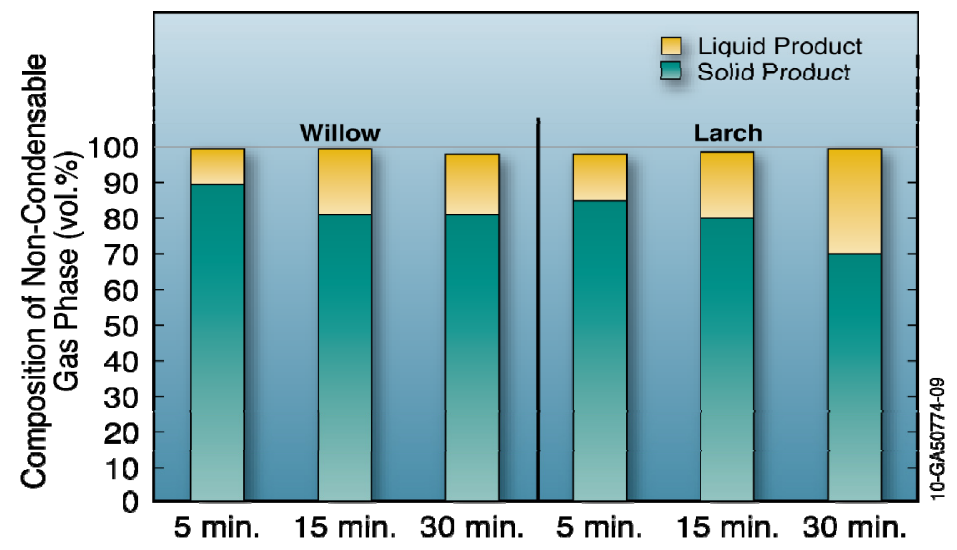

Figure 12. Change in gas composition over time for torrefaction at $250^{\circ} \mathrm{C}$ (Prins, 2005).

Table 13. Gaseous products composition during torrefaction (nitrogen and water free basis).

\begin{tabular}{|c|c|c|c|c|c|c|}
\hline Biomass & $\operatorname{Temp}\left({ }^{\circ} \mathrm{C}\right)$ & Time (h) & $\mathrm{CH}_{4}$ & $\mathrm{C}_{2}$ & $\mathrm{CO}_{2}$ & $\mathrm{CO}$ \\
\hline \multirow[t]{9}{*}{ Birch } & 230 & 1 & 0.08 & bdl & 85.81 & 14.11 \\
\hline & 230 & 2 & 0.10 & 0.04 & 84.2 & 15.66 \\
\hline & 230 & 3 & bdl & 0.04 & 84.07 & 15.89 \\
\hline & 250 & 1 & 0.08 & 0.06 & 83.09 & 16.77 \\
\hline & 250 & 2 & 0.09 & 0.07 & 81.90 & 17.94 \\
\hline & 250 & 3 & 0.13 & 0.08 & 81.24 & 18.55 \\
\hline & 280 & 1 & 0.14 & 0.10 & 78.29 & 21.47 \\
\hline & 280 & 2 & 0.18 & 0.10 & 74.75 & 24.97 \\
\hline & 280 & 3 & 0.27 & 0.14 & 72.70 & 26.89 \\
\hline
\end{tabular}


Table 14. Gas phase composition during torrefaction of willow at $260^{\circ} \mathrm{C}$ for 32 minutes.

\begin{tabular}{lc}
\hline \multicolumn{1}{c}{ Gas phase composition } & Mass yield (\%) \\
\hline $\mathrm{CO}$ & 0.1 \\
$\mathrm{CO}_{2}$ & 3.3 \\
$\mathrm{H}_{2} \mathrm{O}$ & 89.3 \\
Acetic acid & 4.8 \\
Furfural & 0.2 \\
Methanol & 1.2 \\
Formic acid & 0.1 \\
Reminder $\left(\mathrm{CH}_{4}, \mathrm{C}_{\mathrm{x}} \mathrm{H}_{\mathrm{y}}\right.$, toluene, and & 1.0 \\
benzene) & \\
\hline Source: $\mathrm{Kiel}(2007)$. & \\
\hline
\end{tabular}

\section{Significance of the products}

The torrefaction process is a considerable energy densification process, during which chemical energy transfers from the feedstock to the torrefied product, while fuel properties are improved. In addition, to achieve high energy efficiency at low cost, innovative technologies of torrefaction were developed; with Center for Energy Research and Development's (ECN) TOP process one of the most mature (Bergman, 2005), as shown in Figure 13.

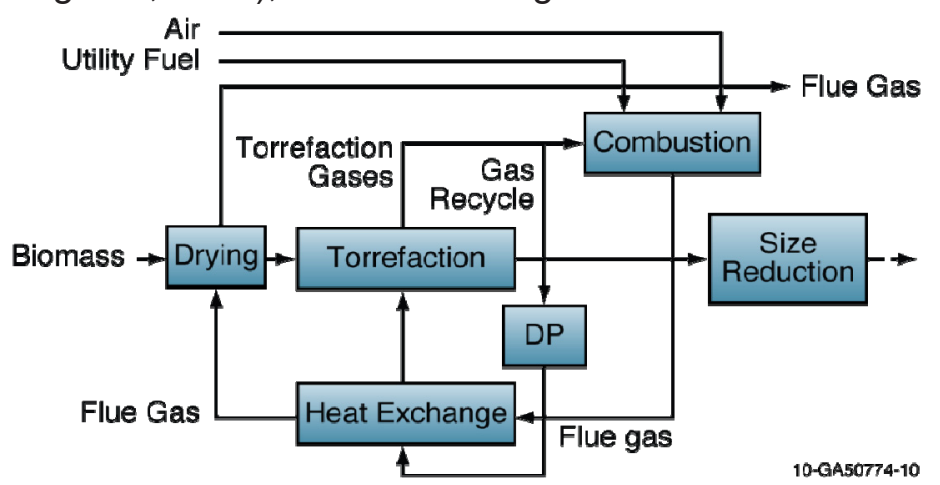

Figure 13. The envisaged conceptual structure of the torrefaction process of ECN.

Figure 11 represents the conceptual structure of the torrefaction process. The depicted process layout is based on the direct heating of biomass during torrefaction by means of hot gas that is recycled. The hot gas consists of the torrefaction gas itself and is re-pressurized to compensate for the pressure drop in the recycle loop. It heats the recycled gas to deliver the required heat demand in the torrefaction reactor. The necessary heat for torrefaction and pre-drying is produced by the combustion of the liberated torrefaction gas. A utility fuel can be used when the energy content of the torrefaction gas is insufficient to thermally balance the torrefaction process and to provide stability and control of the combustion process. Bergman et al. (2005) identified this process concept as the most promising for torrefaction, which achieves autothermal operation when the total heat demand of the process (drying and torrefaction) is balanced by the energy content of the torrefaction gas. The torrefaction conditions (temperature and reaction time or residence time) are the crucial variables to tune the thermal balance (i.e., the energy yield of torrefaction and hence the energy content of the torrefaction gas). 
The torrefaction gas consists of a wide variety of combustible organic components. However, the components that dominate its composition are incombustible (water and $\mathrm{CO}_{2}$ ). From the given product distribution in Tables 17 and 18 and Figures 6, 10, and 12, the torrefaction gas is rather wet. Even when completely dry biomass is torrefied, it is expected that the torrefaction gas has a water content of over $50 \%$ wt and a $\mathrm{CO}_{2}$ content of about $10 \%$ wt. Hence in total the torrefaction gas will at least consist of about $60 \%$ wt of incombustible components. The exact amount will be determined by specific conditions, but also significantly by the moisture content of the biomass feed. In the studies of Bergman et al. (2005) and Bergman (2005), the calculated calorific value of the torrefaction gas was further examined and quantified experimentally. Conversely, the mass and energy balance of the integral process, thermal process efficiency, autothermal operation, and combustibility torrefaction gas were investigated by means of process simulations.

In their studies, the yield of reaction water varied between 5 and $15 \% \mathrm{wt}$, resulting in a concentration of $50-80 \% \mathrm{wt}$ in the torrefaction gas (excluding free water from the feedstock). The reaction water yield increased with reaction time or residence time and temperature, while its concentration decreased. Consequently, the relative contribution of combustible products increases with increased temperature and reaction time or residence time, as does the calorific value, which ranges from 5.3-16.2 MJ/ $\mathrm{Nm}^{3}$. Despite the high water content of the torrefaction gas, the calorific value is relatively high. It can be compared to producer gas from air blown biomass gasification (4-7 $\mathrm{MJ} / \mathrm{Nm}^{3}$ ) and to syngas produced in indirectly heated gasification processes $\left(15-20 \mathrm{MJ} / \mathrm{Nm}^{3}\right)$. On the basis of this comparison, the torrefaction gas should be combustible, and can play an important role in the torrefaction process. Typical experimental results for torrefaction mass and energy yields, and gas phase composition are given in Figure 14.

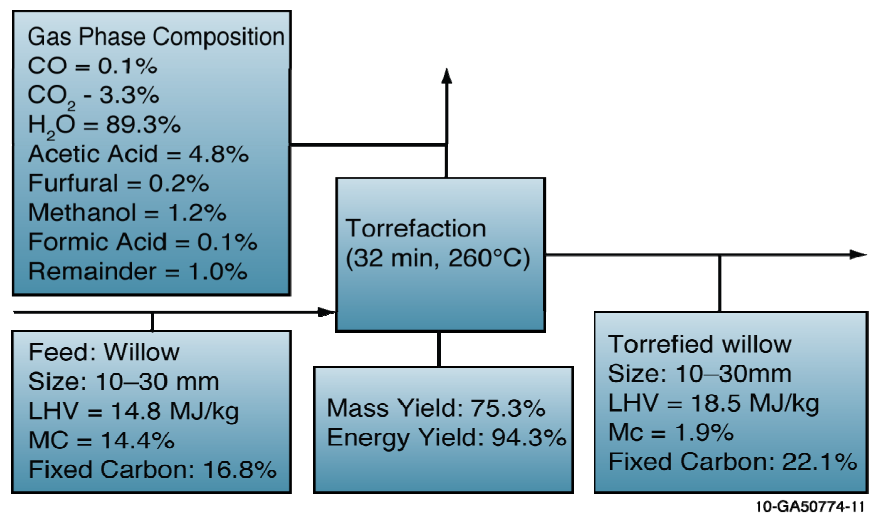

Figure 14. Typical experimental results of torrefaction of willow (Kiel, 2007).

\section{Methods for Torrefaction Off-Gases Analysis}

In order to make an overall mass balance, all the reaction products should be collected and weighed accurately. The solids, liquids, and gases produced are each analyzed using reliable standardized techniques. The following will review the analysis method for volatiles in torrefaction.

In the study of Prins et al. (2006a), the volatile products are split into a liquid and gas phase in a cold trap at $-5^{\circ} \mathrm{C}$. Liquid products collected in the cold trap were diluted with 2-butanol because not all the products dissolved in water. The diluted liquid was analyzed with high performance liquid chromatography (HPLC) using a Chrompack Organic Acids column with detection based 
on refraction index. The composition of the produced gas was analyzed with a Varian Micro gas chromatography (GC) with a Poraplot $Q$ and a Molsieve column.

In the study of Deng et al. (2009), the products were removed from the hot zone to minimize the second reactions between the liquid and char, and to maximize the solid yield. A two-necked flask immersed in liquid nitrogen was used as a trapping system for condensable liquid. Noncondensable gases went through a filter to remove the carbon soot before entering an infrared gas analysis. The gas composition and concentration were recorded continuously throughout the heating process. Finally, the weight of the biochar and the amount of liquids obtained were measured.

In the study of Bridgeman (2008) a Nicolet Magma-IR AEM connected to a Stanton Redcroft Simultaneous Analyser STA-780 Series was used to perform torrefaction experiments at laboratory scale while simultaneously analyzing the volatile pyrolysis products for corresponding Thermogravemetric analyzer (TGA) data.

In addition, the analysis of biomass tar can also be used for reference. In the study of Dufour et al. (2007), two methods for the sampling and analysis of tar produced from wood pyrolysis were compared. The first method used a conventional cold-trapping technique in solvent-filled impingers followed by liquid injection. The second one is a new application of multi-bed solidphase adsorbent (SPA) tubes followed by thermal desorption (TD). Both methods are based on GC coupled with mass spectrometry (MS). Quantification was performed with a well reproducible GC-MS method with three internal deuterated standards.

\section{Storage Aspects of Torrefied Biomass}

\section{Off-gassing}

Storage issues like off-gassing and self-heating may also be insignificant in torrefied biomass as most of the solid, liquid, and gaseous products that are chemically and microbiologically active are removed during the torrefaction process. Kuang et al. (2009) and Tumuluru et al (2010) studies on wood pellets concluded that high storage temperatures of $50^{\circ} \mathrm{C}$ can result in high $\mathrm{CO}$ and $\mathrm{CO}_{2}$ emissions, and the concentrations of these off-gases can reach up to $6 \%$ for a 60 -day storage period. These emissions were also found to be sensitive to relative humidity and product moisture content. The same researchers at University of British Columbia has conducted studies on off-gassing from torrefied wood chips and indicated that $\mathrm{CO}$ and $\mathrm{CO}_{2}$ emissions were very low; nearly one third's of the emissions from regular wood chips at room temperature $\left(20^{\circ} \mathrm{C}\right)$. The reason could be due to low moisture content and reduced volatile content which could result in less reactivity with the storage environment.

\section{Hydrophobicity}

An advantage of torrefied pellets over regular raw pellets is that they are hydrophobic (moisture uptake is almost negligible) even under severe storage conditions. In general, the uptake of water by raw biomass is due to the presence of $\mathrm{OH}$ groups. Torrefaction produces a hydrophobic product by destroying $\mathrm{OH}$ groups and causing the biomass to lose the capacity to form hydrogen bonds (Pastorova et al., 1993). Due to these chemical rearrangement reactions, non-polar unsaturated structures are formed, which preserve the biomass for a long time without biological degradation, similar to coal (Bergman and Kiel, 2005; Wooten et al., 2000).

Bergman (2005) determined the hydrophobicity of torrefied pellets by immersing them in water for 15 hours. The hydrophobic nature was evaluated based on the state of the pellet after this 
period and by gravimetric measurement to determine the degree of water uptake. Bergman (2005) study indicated that raw pellets swelled rapidly and disintegrated into original particles. Torrefied pellets produced under optimal conditions, however, did not disintegrate and showed little water uptake (7-20\% on mass basis). He also concluded that torrefaction conditions play a vital role in the hydrophobic nature of biomass. Sokhansanj et al. (2010) compared the moisture uptake of the torrefied biomass to the untreated biomass and found that there is about a $25 \%$ decrease in the water uptake when compared to the control (Figure 15).

Biomass is porous, often moist, and prone to off-gassing and self heating due to chemical oxidation and microbiological activity. In general, the biomass moisture content plays an important role in initiating chemical and microbial reactions. Moisture content coupled with high storage temperatures can cause severe off-gassing and self-heating from biomass-based fuels. Another important storage issue of ground torrefied biomass is its reactivity in powder form, which can result in fire during storage. It is preferred to store the torrefied biomass in an inert environment to avoid accidents due spontaneous combustion. Kiel (2007) in his laboratory-scale combustion studies of torrefied wood found that it is highly reactive, similar to coal.

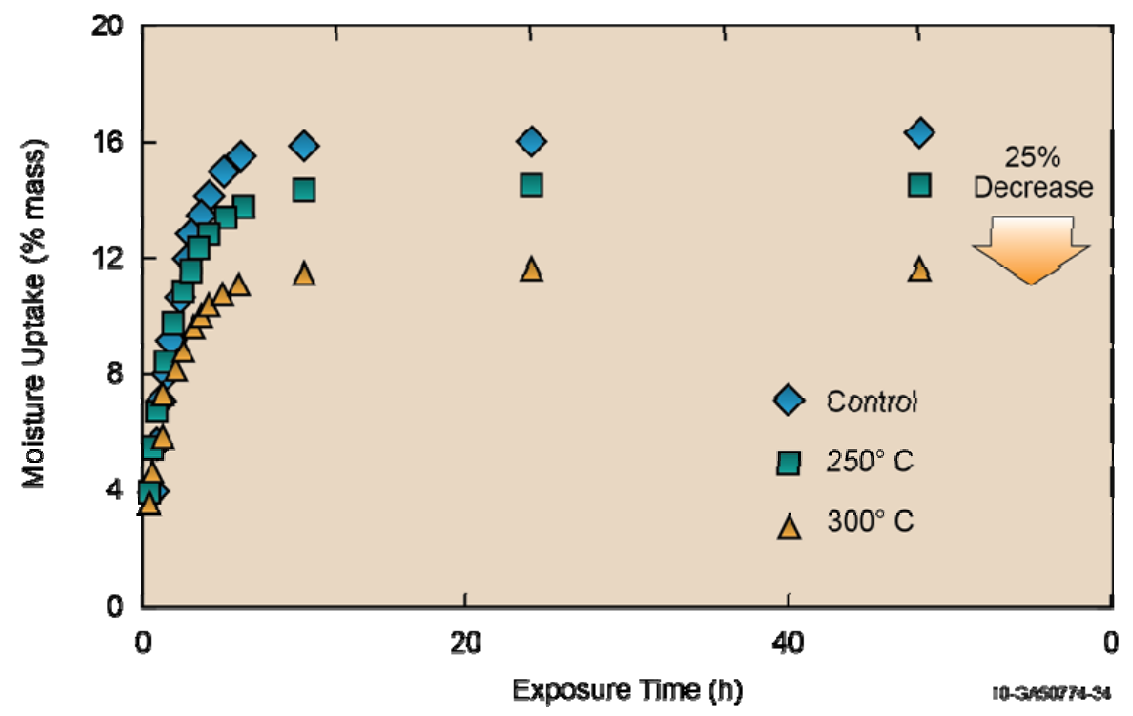

Figure 15. Moisture uptake by the torrefied wood pellets made from 0.8-mm particle size.

\section{Torrefied Biomass Applications}

Pulverized fuel combustion in coal-fired power stations and entrained flow gasification are particularly interesting product outlets for biomass. In both applications, biomass has to be fed to the reactor as a powder, which is difficult, costly, and achievable only at very low capacity in classical coal-mills. Due to this limitation, wood pellets are currently the state-of-the-art for cofiring, as they consist of sufficiently small particles. Consequently, wood pellets also have some limitations in terms of energy content and moisture uptake during storage and transportation. Torrefied biomass being energy dense and hydrophobic in nature can be a good replacement for wood pellets in co-firing and gasification plants. The high fuel quality of torrefied biomass makes it very attractive for combustion and gasification applications. Due to high CVs, the thermal energies of the combustion and gasification system can be improved significantly (Bergman and Kiel, 2005). However, there is no data on milling, handling, storing, transporting, and combusting large amounts of torrefied biomass at a commercial scale. Other applications 
include (1) high-quality smokeless solid fuels for industrial, commercial, and domestic applications; (2) solid fuel for cofiring directly with pulverized coal at electric power plants; (3) an upgraded feedstock for fuel pellets, briquettes, and other densified biomass fuels; and (4) high quality biomass solid fuel for advanced bioenergy application.

\section{Moving Bed Torrefier Model Development}

Based on the fundamental concepts of the torrefaction process, a model torrefaction system based on a moving bed concept was developed. The following criteria were used in establishing the model design:

- Minimize the volume and footprint of the system

- Combine several functions into a single unit

- Accept a wide range of particle sizes

- Minimize fixed and operational costs.

After reviewing several torrefaction systems such as screw auger, cascading trays (Wyssmont), horizontal moving bed, and batch units, a decision was made to model a moving bed reactor that combines drying and torrefaction. This system is similar to TORSPYD system available at the following website: http://www.biomass-torrefaction.com/pdf/torrefaction_torspyd.pdf. The system shown on the website gives the overall outline as shown in Figure 16.

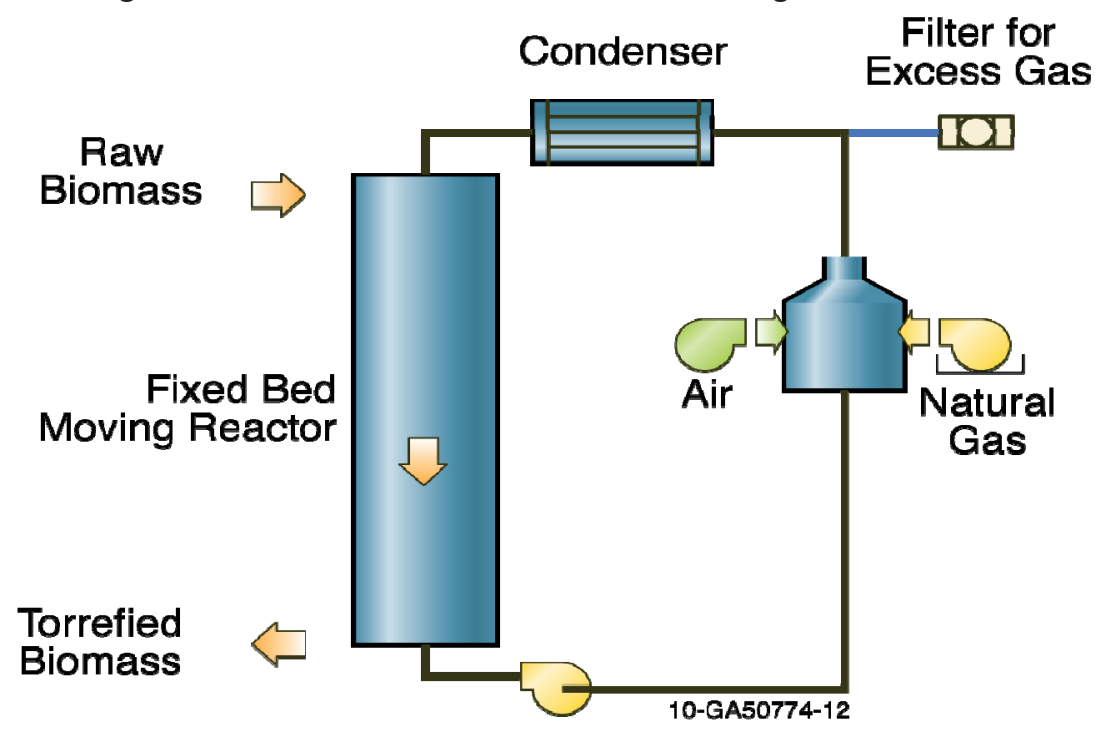

Figure 16. Overall drying and torrefying system.

Raw solid biomass particles enter from the top of the reactor. The particles undergo drying and torrefaction and exit at the bottom of the reactor. Neutral (oxygen free) hot gases enter the bottom of the column and travel upward. The loaded gases exit the top of the reactor. A condenser extracts water vapor and other condensable substances from the gas. Dry gas is combusted in a burner to generate hot gases for recirculation through the reactor. Excess gas is filtered before releasing it to the environment. 


\section{Reactor}

In the following sections, we describe procedures used to calculate the initial sizing of each subsystem within the reactor. Figure 17 shows the preliminary configuration of the reactor. Biomass particles enter a hopper at the top of the reactor. The material is then passed through an airlock as it fills up the entire length of the column. The bottom of the reactor is a hopper leading to an airlock and a screw conveyor. The function of the screw conveyor is to cool the hot torrefied material to a temperature below its ignition temperature.

As the biomass travels down in the column, it goes through several treatments; heating, drying, heating, torrefying, and finally cooling through the screw conveyor. The reactor is divided into 5 distinct zones: (A) heating zone up to drying temperature, (B) drying zone, (C) heating zone up to torrefying temperature, (D) torrefying zone. The height of the reactor column is determined by the flow rate of the material and the material residence times in zones A, B, C, and D. The cooling zone $\mathrm{E}$ does not contribute to the length of the column and is dealt with separately.

\section{Temperature Profile of Solid Material}

Figure 18 and Figure 19 depict temperature and mass of solid materials as they pass through zones $A, B, C$, and $D$. The $X$-axis is the distance the material travels in each zone. The length of travel must be such that the material remains in that zone until the reaction is complete. Zone $A$ is where the initial preheating takes place. In this zone the wet, cool, and raw biomass is heated to a temperature at which drying takes place. We assume that the moisture content of the material does not change until it reaches the drying temperature of $100^{\circ} \mathrm{C}$. In Zone $\mathrm{B}$, the temperature remains constant at $100^{\circ} \mathrm{C}$ while the material loses its moisture. In Zone $\mathrm{C}$, the material's temperature increases to the desired torrefaction temperature. At this temperature, the material will lose a fraction of its weight to volatiles. The total height of the reactor is the sum of distance the biomass travels while passing through zones $A, B, C$, and $D$. In the following sections, the methods used to estimate the distance or time for each zone is described.

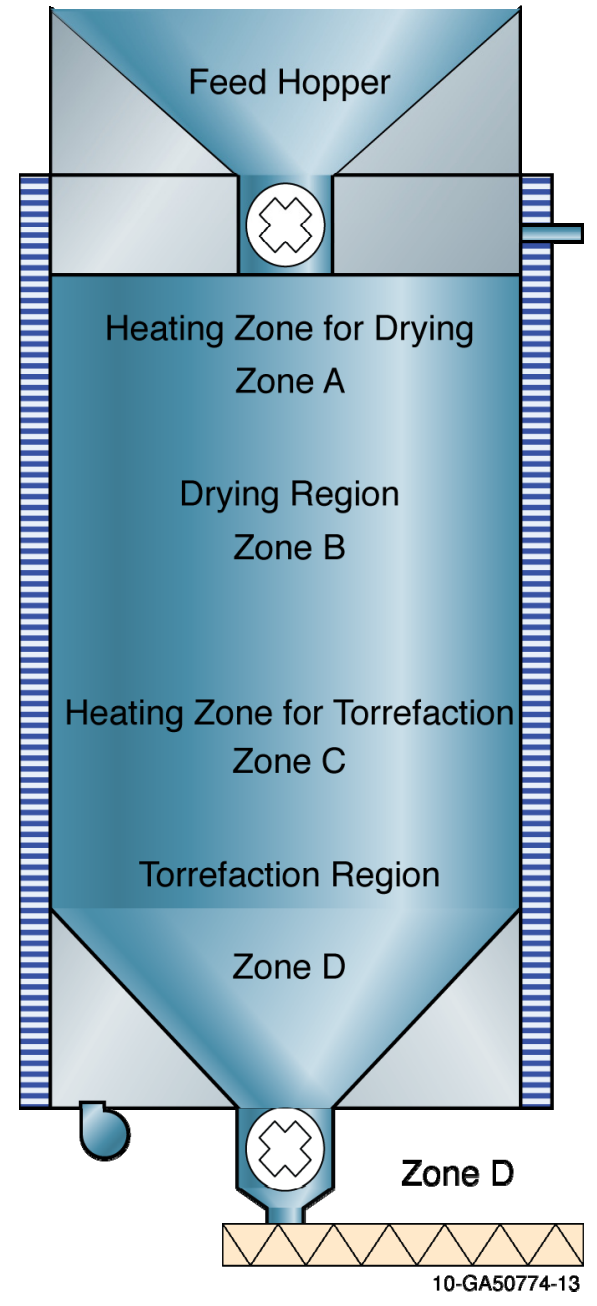

Figure 17. INL moving bed torrefier reactor. 


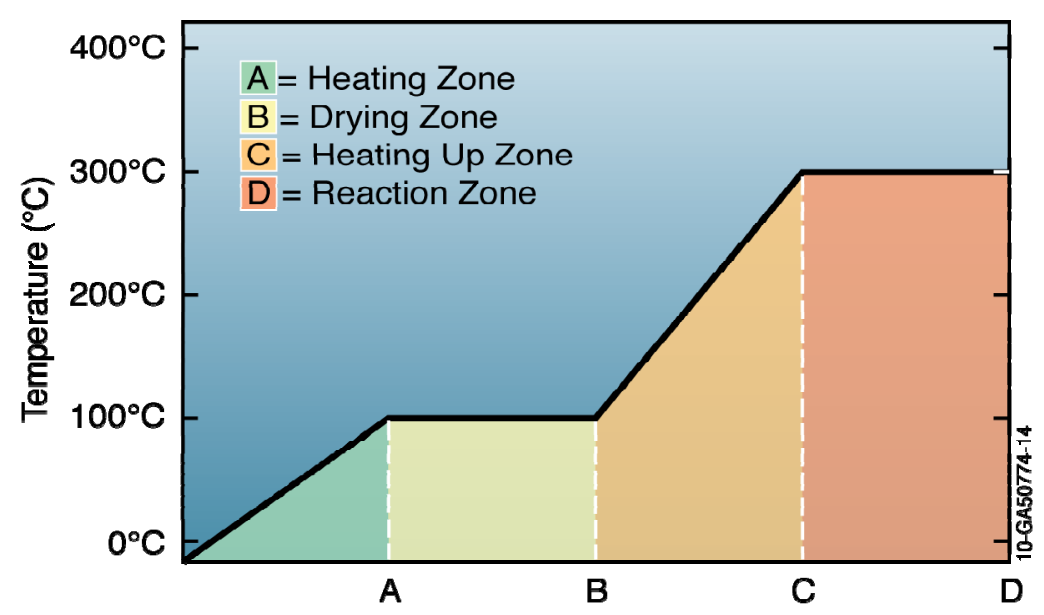

Figure 18. Different temperature zones in a torrefier.

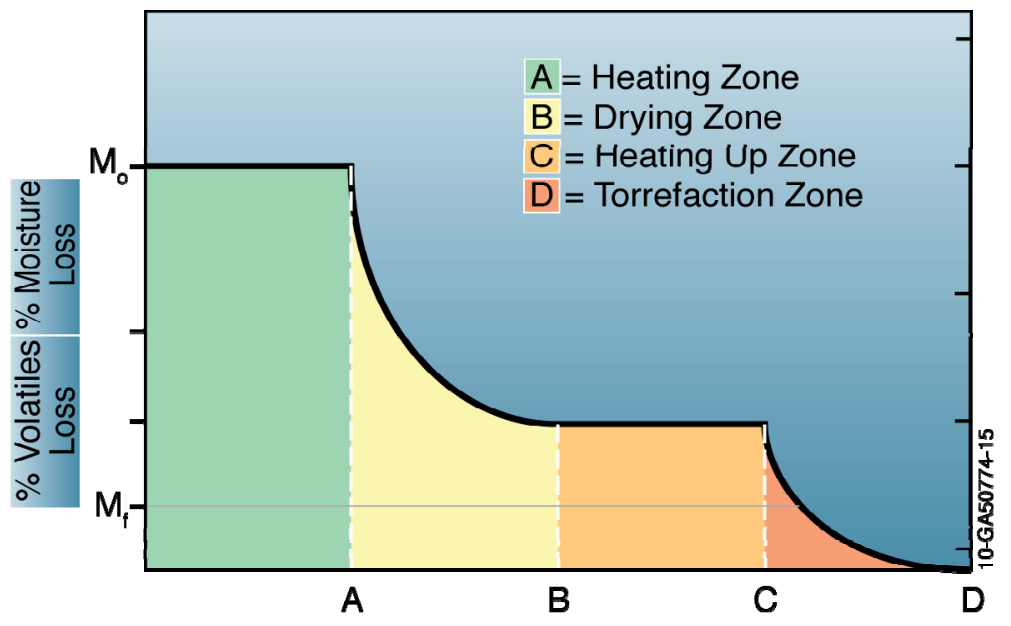

Figure 19. Mass of biomass as it passes through the torrefier.

\section{Design Calculations}

\section{Height of Torrefier for Different Zones}

\section{Zone A-Heating Zone up to Drying Temperature}

It is assumed that in Zone $A$, the biomass temperature will rise from its initial temperature when it enters the zone to an equilibrium temperature with the air. The transfer of energy takes place through convection. It is also assumed that all of the material in Zone A has the same temperature. This is shown in Equation (1).

$$
\frac{T-T_{e}}{T_{o}-T_{e}}=e^{-\left(\frac{h S}{\rho C V}\right) t}
$$

where $T$ is temperature at time $t, T_{e}$ is equilibrium temperature, $T_{o}$ is initial temperature, $h$ is the average heat transfer coefficient $\left(\mathrm{W} / \mathrm{m}^{2}{ }^{\circ} \mathrm{K}\right), S$ is total surface area $\mathrm{m}^{2}$ of solid particles in the zone, $\rho$ is the bulk density $\left(\mathrm{kg} / \mathrm{m}^{3}\right)$ of material in Zone $A, C$ is its specific heat of material $\left(\mathrm{J} / \mathrm{kg}^{\circ} \mathrm{K}\right)$, and $V$ is the volume of the zone $\left(\mathrm{m}^{3}\right)$. 
We can run an experiment with a bulk material in an oven and record temperatures versus time. For the material we can then estimate the value of the group with Equation (2):

$\tau=\left(\frac{h S}{\rho C V}\right)^{-1}$

where $\square$ is a time constant for the materials. Typical values are given in Table 15.

Table 15. Example values used in Equation 1.

\begin{tabular}{l|l|l|l|l|l|l|l|l}
\hline \multicolumn{1}{c|}{$h$} & \multicolumn{1}{c|}{$S$} & \multicolumn{1}{c|}{$V$} & & \multicolumn{1}{c|}{$\rho$} & \multicolumn{1}{c|}{$\mathrm{C}$} & \multicolumn{1}{c|}{$T_{e}$} & \multicolumn{1}{c|}{$T_{o}$} & \multicolumn{1}{c}{$T$} \\
\hline $\mathrm{W} /\left(\mathrm{m}^{2}{ }^{\circ} \mathrm{K}\right)$ & $\mathrm{m}^{2}$ & $\mathrm{~m}^{3}$ & Decimal & $\mathrm{kg} / \mathrm{m}^{3}$ & $\mathrm{~J} /(\mathrm{kg} \mathrm{K})$ & ${ }^{\circ} \mathrm{C}$ & ${ }^{\circ} \mathrm{C}$ & ${ }^{\circ} \mathrm{C}$ \\
\hline 10 & $\begin{array}{l}0.0020 \\
8\end{array}$ & $\begin{array}{l}0.000003 \\
2\end{array}$ & 0.5 & 150 & 2000 & 160 & 20 & 100 \\
\hline
\end{tabular}

Surface area and volume are calculated for a particle with dimensions $4 \mathrm{~mm} \times 20 \mathrm{~mm} \times 40 \mathrm{~mm}$.

$\tau=\left(\frac{(10)(0.00208)}{(150)(2000)(0.0000032 / 0.5)}\right)^{-1}(60)=0.39(1 /$ minute $)$

For temperature

$T R=\frac{T-T e}{T o-T e}=\frac{100-160}{20-160}=0.43$

Heating time is calculated by

$t=-\operatorname{Ln}(0.43) / 0.39=2.69$ minutes

The required heat to raise the temperature of the biomass is

$Q_{h}=m_{p} C_{p} \Delta T$

Zone B-Drying Zone

In Zone B the biomass loses its weight by moisture evaporation. Drying temperature remains constant. Similar to the heating zone, the moisture transfer equation can be expressed by Equation (7).

$$
\frac{M-M_{e}}{M_{o}-M e}=e^{-k t^{n}}
$$

where $M, M_{e}$, and $M_{o}$ are moisture content at time t, equilibrium, and initial moisture content. $k$ is the drying constant for the material. Constant $n$ is an exponent that improves the performance of the drying. For wood chips,

$$
\operatorname{Ln}(k)=-2200(1 / T)+2.76
$$

where $T$ is in Kelvin $\left(273+\operatorname{temp~}^{\circ} \mathrm{C}\right)$ and $k$ is the drying constant in $1 / \mathrm{min}$.

Typical values are given in Table 20. All moisture contents are decimal fractions of the dry mass.

$$
\frac{0.10-0.0}{0.75-0.0}=e^{-0.09 t^{1.15}}
$$


where $t=13.8$

Other values used in these calculations are in Table 16.

Table 16. Sample values used in Equation 7.

\begin{tabular}{|c|c|c|c|c|c|}
\hline$k$ & $n$ & $M$ & $M_{e}$ & $M_{0}$ & $\rho$ \\
\hline $1 / \mathrm{min}$ & - & Dry basis & Dry basis & Dry basis & $\mathrm{kg} / \mathrm{m}^{3}$ \\
\hline 0.09 & 1.15 & 0.10 & 0.0 & 0.75 & 150 \\
\hline
\end{tabular}

Zone C-Heating Zone up to Torrefaction Temperature

In Zone C, the dried material's temperature rises to torrefying temperature, $250^{\circ} \mathrm{C}$. The heating process is similar to the heating process in Zone A, shown in Equation (10):

$\frac{T-T_{f}}{T_{o}-T_{f}}=e^{-\left(\frac{h S}{\rho C_{p} V}\right) t}$

where $T$ is temperature at time $t, T_{f}$ is equilibrium temperature at which the torrefaction reaction takes place, $T_{o}$ is the initial temperature, $h$ is the average heat transfer coefficient $\left(\mathrm{W} / \mathrm{m}^{2} . \mathrm{K}\right), S$ is total surface area of solid particles in the zone, pis the bulk density of material in Zone $\mathrm{C}, \mathrm{Cp}$ is its specific heat, and $V$ is the volume of the zone.

We can run an experiment with a bulk material in an oven and record temperatures versus time. For the material we can then estimate the value of the group, using Equation (11) (Table 17):

$\tau=\left(\frac{h S}{\rho C_{p} V}\right)^{-1}$

Table 17. Sample values used in Equation 11.

\begin{tabular}{|c|c|c|c|c|c|c|c|}
\hline$h$ & $S$ & $V$ & $\rho$ & $C$ & $T e$ & $T o$ & $T$ \\
\hline $\mathrm{W} /\left(\mathrm{m}^{2} \mathrm{~K}\right)$ & $\mathrm{m}^{2}$ & $\mathrm{~m}^{3}$ & $\mathrm{~kg} / \mathrm{m}^{3}$ & $\mathrm{~J} /\left(\mathrm{kg}^{\circ} \mathrm{K}\right)$ & ${ }^{\circ} \mathrm{C}$ & ${ }^{\circ} \mathrm{C}$ & ${ }^{\circ} \mathrm{C}$ \\
\hline 15 & 0.00208 & 0.0000032 & 150 & 2000 & 300 & 150 & 250 \\
\hline
\end{tabular}

Surface area and volume are calculated for a particle with dimensions $4 \mathrm{~mm} \times 20 \mathrm{~mm} \times 40 \mathrm{~mm}$.

$\tau=\left(\frac{(15)(0.00208)}{(150)(2000)(0.0000032 / 0.5)}\right)^{-1}(60)=0.975$ (1/minute)

For temperature

$T R=\frac{T-T e}{T o-T e}=\frac{250-300}{150-300}=0.33$

Heating time is calculated by

$t=-\operatorname{Ln}(0.33) / 0.975=1.13$

where $t$ is time in minutes. 


\section{Zone D-Torrefaction}

The torrefaction process is similar to the drying process where the material goes through a breakdown of the constituents, resulting in loss of volatiles. In Zone $D$, the biomass loses its weight through the breakdown of chemical constituents and loss of volatiles. We assume torrefaction temperature remains constant during this process. Similar to Zone $\mathrm{B}$, the loss of volatiles will follow Equation (15).

$$
\frac{m-m_{e}}{m_{o}-m e}=e^{-k t^{n}}
$$

where $m, m_{e}$, and $m_{o}$ are the mass concentration of volatiles at time $t$, equilibrium, and initial volatile content. $k$ is the mass loss constant for the material. For wood chips,

$k=A \exp \left(\frac{-E}{R T}\right)$

The values of $A, E$, and $R$ are listed in Table $22 . T$ is in Kelvin $\left(273+\right.$ temp $\left.{ }^{\circ} \mathrm{C}\right)$ and $k$ is the drying constant in $1 / \mathrm{min}$. Typical values are given in the Table 18. All moisture contents are decimal fractions of the dry mass (Table 19).

Table 18. Constants for the reaction kinetics of Equation 17.

\begin{tabular}{lccc}
\hline \multicolumn{1}{c}{ Species } & $A$ & $E$ & $R$ \\
\hline Pine & 2.64 & 77.080 & 8.3144 \\
Fir & 3.01 & 88.760 & 8.3144 \\
Pine bark & 2.72 & 44.410 & 8.3144 \\
Mix Spruce, Pine, Fir (SPF) & 2.30 & 76.680 & 8.3144 \\
\hline
\end{tabular}

Table 19. Sample values for use in Equations 14 and 15.

\begin{tabular}{ccccccc}
\hline$K($ pine $)$ & $n$ & $m$ & $m e$ & $m o$ & $\rho$ & $T$ \\
\hline $1 / \mathrm{min}$ & - & Dry basis & Dry basis & Dry basis & $\mathrm{kg} / \mathrm{m}^{3}$ & ${ }^{\circ} \mathrm{C}$ \\
\hline 0.09 & 1.0 & 0.10 & 0.0 & 0.35 & 150 & 250 \\
\hline
\end{tabular}

\section{Bulk Density}

The bulk density of the biomass changes as it goes through drying and torrefaction stages (Table 20). We can write the bulk density as a function of its constituents as shown in Equation (17).

$$
\rho=\frac{1}{\frac{X_{w}}{\rho_{w}}+\frac{X_{v}}{\rho_{v}}+\frac{X_{s}}{\rho_{s}}}
$$

where $\rho$ is the bulk density and $\mathrm{X}$ is the mass fraction of the constituents. Subscripts $w, v$, and $s$ are for water, volatiles (substances before becoming volatile), and solid. 
Table 20. Densities and mass fractions based on Equation 17.

\begin{tabular}{ccccccc}
\hline$\rho_{\mathrm{w}}$ & $\rho_{\mathrm{v}}$ & $\rho_{\mathrm{s}}$ & $X_{\mathrm{w}}$ & $X_{\mathrm{v}}$ & $X_{\mathrm{s}}$ & $\rho$ \\
\hline $\mathrm{kg} / \mathrm{m}^{3}$ & $\mathrm{~kg} / \mathrm{m}^{3}$ & $\mathrm{~kg} / \mathrm{m}^{3}$ & $\mathrm{~kg} / \mathrm{kg}$ & $\mathrm{kg} / \mathrm{kg}$ & $\mathrm{kg} / \mathrm{kg}$ & $\mathrm{kg} / \mathrm{m}^{3}$ \\
\hline 1000 & 150 & 250 & 0.25 & 0.35 & 0.40 & 293 \\
\hline
\end{tabular}

The sum of mass fractions equals 1

$X_{w}+X_{v}+X_{s}=1$

or

$X_{v}+X_{s}=1-X_{w}$

We assume

$X_{v}=X_{s}$

$X_{s}=\frac{1-X_{w}}{2}$

\section{Height of the Truncated Cone}

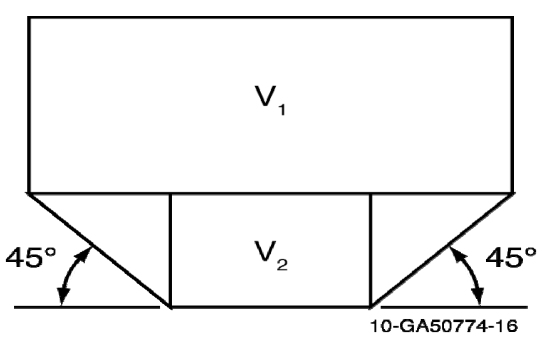

Figure 20. Shape of truncated cone.

$\mathrm{A}=1.13 \mathrm{~m}^{2}$

$\mathrm{V}_{2}=0.226 \mathrm{~m}^{3}$

$\mathrm{V}_{1}=2.274 \mathrm{~m}^{3}$

Height of the torrefaction region: $\mathrm{V}_{1} / \mathrm{A}=2.012 \mathrm{~m}$

In these calculations we assume that the ratio of the height of the torrefier over the diameter is around 5.

Total height of the torrefaction reactor: Zone A + Zone B + Zone C + Zone D.

\section{Gas Flow Rate}

1. Calculation of gas

2. Calculation of Nitrogen

3. Heat balance 


\section{Design of Moving Bed Torrefaction System Model Development Using an Excel Sheet}

Based on the design calculations an interactive excel calculation sheet was developed for calculating heights of different columns of moving bed torrefaction systems (fig.17) heat required, nitrogen flow rates, pressure drop and blower capacity for different capacities of the moving bed ranging from $25 \mathrm{~kg} / \mathrm{hr}$ to $1000 \mathrm{~kg} / \mathrm{hr}$.

\begin{tabular}{|c|c|c|c|c|}
\hline Sizing a Thermal Treatment Unit & & \multicolumn{2}{|c|}{ Yellow marked cells are for inputs. } & \\
\hline \multicolumn{5}{|l|}{ Different zones } \\
\hline Zone A Heating Zone & Density of water $\left(\mathrm{kg} / \mathrm{m}^{3}\right)$ & 1000 Specific heat of water & CW (J/kg. K) & 4200 \\
\hline Zone B Drying Zone & Density of voltiles $\left(\mathrm{kg} / \mathrm{m}^{3}\right)$ & 150 Specific heat of dry matter & $\mathrm{Cd}(\mathrm{J} / \mathrm{kg} . \mathrm{K})$ & 2000 \\
\hline Zone $\mathrm{C}$ Heating Zone for torrefaction & Density of solids $\left(\mathrm{kg} / \mathrm{m}^{3}\right)$ & 250 Specific heat of air & $\mathrm{Ca}(\mathrm{J} / \mathrm{kg} \cdot \mathrm{K})$ & 1005 \\
\hline \multirow[t]{4}{*}{ Zone D Torrefaction Zone } & Bulk porosity (decimal fraction) & 0.4 Specific heat of nitrogen & $\mathrm{Cn}(\mathrm{J} / \mathrm{kg} . \mathrm{C})$ & 1005 \\
\hline & Density of nitrogen $\left(\mathrm{kg} / \mathrm{m}^{3}\right)$ & 0.75 Heat of vaporization & hfg (kJ/kg) & 2240 \\
\hline & & Heat of volatilization & hvg (kJ/kg) & 2240 \\
\hline & & Heat value of volatiles & $(\mathrm{MJ} / \mathrm{kg})$ & 4 \\
\hline
\end{tabular}




\section{Base Case}

Torrefaction Region (Zone D)

Output (kg/h) (dry torrefied material)

Initial moisture content

Final moisture content

Initial volatile concentration

Final volatile concentration

Initial solid concentration

Final solid concentration

Initial bulk density $\left(\mathrm{kg} / \mathrm{m}^{3}\right)$

Final bulk density $\left(\mathrm{kg} / \mathrm{m}^{3}\right)$

Initial mass flow rate $(\mathrm{kg} / \mathrm{hr})$

Final mass flow rate $(\mathrm{kg} / \mathrm{hr})$

Initial volume flow rate $\left(\mathrm{m}^{3 /} \mathrm{hr}\right)$

Final volume flow rate $\left(\mathrm{m}^{3} / \mathrm{hr}\right)$

Average volume flow rate $\left(\mathrm{m}^{3} / \mathrm{hr}\right)$

Equilibrium concentration of volatiles

Concentration of voltailes at $t$

Constant A

Constant $E$

Constant R

Reaction temperature $T$

Torrefaction constant

Mass ratio

Residence time : $\min$

Diameter of the column: $m$

Diameter of the exit port

Slope of hopper a

Height (h) m (D1-D2)/2*tan(a)

Area: $\mathrm{m}^{2}$

Volume of truncated cone: $V_{2}$

Volume flow $\left(\mathrm{m}^{3} / \mathrm{hr}\right)$

Volume $\mathrm{V} 1+\mathrm{V} 2\left(\mathrm{~m}^{3}\right)$

Volume of straight cylinder $(\mathrm{m})$

Height of straight section (m)

Total height of Zone D (m)

Total mass $(\mathrm{kg})$

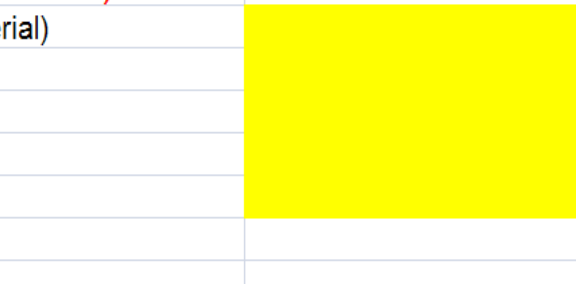

$\begin{array}{rr}1000 & 750 \\ 0.05 & 0.05 \\ 0 & \\ 0.35 & 0.35 \\ 0.1 & 0.1 \\ 0.6 & 0.6 \\ 0.9 & 0.9\end{array}$

$125.4 \quad 125.4$

$140.6 \quad 140.6$

1400.01050 .0

$1100.0 \quad 825.0$

$11.16 \quad 8.37$

\begin{tabular}{ll|l}
7.82 & 5.87
\end{tabular}

$9.49 \quad 7.12$

$0.00 \quad 0.00$

$0.15 \quad 0.15$

$2.64 \quad 2.64$

$77.08 \quad 77.08$

$8.31 \quad 8.31$

250.00250 .00

$2.59 \quad 2.59$

$\begin{array}{ll}0.71 & 0.71\end{array}$

\begin{tabular}{ll}
$7.78 \quad 7.78$ \\
\hline
\end{tabular}

$\begin{array}{ll}0.98 & 0.89\end{array}$

$\begin{array}{ll}0.30 & 0.30\end{array}$

$60 \quad 60$

$0.59 \quad 0.51$

$0.76 \quad 0.62$

\begin{tabular}{ll}
$0.16 \quad 0.12$ \\
\hline
\end{tabular}

$9.5 \quad 7.1$

$\begin{array}{ll}1.231 & 0.924\end{array}$

\begin{tabular}{ll}
$1.07 \quad 0.80$ \\
\hline
\end{tabular}

$1.41 \quad 1.29$

\begin{tabular}{|l|l|}
2.00 & 1.80 \\
\hline
\end{tabular}

163.8122 .9

0
5
0
5
1

0

0.35
0.1

0.6

0.9

125.4

140.6

700.0

550.0

5.58

3.91

4.75

0.00

0.15

2.64

77.08

8.31

250.00

2.59

0.71

7.78

0.78

0.26

60

0.45

0.48

0.08

4.7

0.616

0.54

1.12

1.57

81.9

250
0.05
0
0.35
0.1
0.6

125.4

140.6

350.0

275.0

2.79

1.96

2.37

0.00

0.15
2.64

2.64

77.08

8.31

250.00

2.59

0.71

7.78

0.62

0.21

60

0.36

0.30

0.04

2.4
0.308

0.27

0.89

1.25

41.0

\begin{tabular}{|r|r|r|r|}
\hline 150 & 100 & 50 & 25 \\
\hline 0.05 & 0.05 & 0.05 & 0.05 \\
\hline 0 & 0 & 0 & 0 \\
\hline 0.35 & 0.35 & 0.35 & 0.35 \\
\hline 0.1 & 0.1 & 0.1 & 0.1 \\
\hline 0.6 & 0.6 & 0.6 & 0.6 \\
\hline 0.9 & 0.9 & 0.9 & 0.9 \\
\hline 125.4 & 125.4 & 125.4 & 125.4 \\
\hline 140.6 & 140.6 & 140.6 & 140.6 \\
\hline 10.0 & 140.0 & 70.0 & 35.0 \\
\hline 165.0 & 110.0 & 55.0 & 27.5 \\
\hline 1.17 & 1.12 & 0.56 & 0.28 \\
\hline 1.42 & 0.78 & 0.39 & 0.20 \\
\hline 0.00 & 0.00 & 0.47 & 0.24 \\
\hline 0.15 & 0.15 & 0.15 & 0.00 \\
\hline 2.64 & 2.64 & 2.64 & 2.64 \\
\hline 77.08 & 77.08 & 77.08 & 77.08 \\
\hline 8.31 & 8.31 & 8.31 & 8.31 \\
\hline 50.00 & 250.00 & 250.00 & 250.00 \\
\hline 2.59 & 2.59 & 2.59 & 2.59 \\
\hline 0.71 & 0.71 & 0.71 & 0.71 \\
\hline 7.78 & 7.78 & 7.78 & 7.78 \\
\hline 0.52 & 0.45 & 0.36 & 0.29 \\
\hline 0.17 & 0.15 & 0.12 & 0.10 \\
\hline 60 & 60 & 60 & 60 \\
\hline 0.30 & 0.26 & 0.21 & 0.17 \\
\hline 0.15 & 0.16 & 0.10 & 0.06 \\
\hline 1.06 & 0.92 & 0.73 & 0.58 \\
\hline 24.6 & 16.4 & 8.2 & 4.1 \\
\hline 0.16 & 0.02 & 0.01 & 0.00 \\
\hline 0.12 & 0.9 & 0.5 & 0.2 \\
\hline
\end{tabular}


Drying Section Zone B

\begin{tabular}{|c|c|c|c|c|c|c|c|c|}
\hline Initial moisture content & 0.4 & 0.4 & 0.4 & 0.4 & 0.4 & 0.4 & 0.4 & 0.4 \\
\hline Final moisture content & 0.1 & 0.1 & 0.1 & 0.1 & 0.1 & 0.1 & 0.1 & 0.1 \\
\hline Initial volatile concentration & 0.3 & 0.3 & 0.3 & 0.3 & 0.3 & 0.3 & 0.3 & 0.3 \\
\hline Final volatile concentration & 0.45 & 0.45 & 0.45 & 0.45 & 0.45 & 0.45 & 0.45 & 0.45 \\
\hline Initial solid concentration & 0.3 & 0.3 & 0.3 & 0.3 & 0.3 & 0.3 & 0.3 & 0.3 \\
\hline Final solid concentration & 0.45 & 0.45 & 0.45 & 0.45 & 0.45 & 0.45 & 0.45 & 0.45 \\
\hline Initial bulk density $\left(\mathrm{kg} / \mathrm{m}^{3}\right)$ & 166.7 & 166.7 & 166.7 & 166.7 & 166.7 & 166.7 & 166.7 & 166.7 \\
\hline Final bulk density $\left(\mathrm{kg} / \mathrm{m}^{3}\right)$ & 122.4 & 122.4 & 122.4 & 122.4 & 122.4 & 122.4 & 122.4 & 122.4 \\
\hline Initial mass flow rate $(\mathrm{kg} / \mathrm{hr})$ & 1700.0 & 1275.0 & 850.0 & 425.0 & 255.0 & 170.0 & 85.0 & 42.5 \\
\hline Final mass flow rate (kg/hr) & 1550.0 & 1162.5 & 775.0 & 387.5 & 232.5 & 155.0 & 77.5 & 38.8 \\
\hline Initial volume flow rate $\left(\mathrm{m}^{3} / \mathrm{hr}\right)$ & 10.20 & 7.65 & 5.10 & 2.55 & 1.53 & 1.02 & 0.51 & 0.26 \\
\hline Final volume flow rate $\left(\mathrm{m}^{3} / \mathrm{hr}\right)$ & 12.66 & 9.49 & 6.33 & 3.16 & 1.90 & 1.27 & 0.63 & 0.32 \\
\hline Average volume flow rate $\left(\mathrm{m}^{3} / \mathrm{hr}\right)$ & 11.43 & 8.57 & 5.71 & 2.86 & 1.71 & 1.14 & 0.57 & 0.29 \\
\hline Drying temperature: $\mathrm{T}^{\circ} \mathrm{C}$ & 150 & 150 & 150 & 150 & 150 & 150 & 150 & 150 \\
\hline Equilibrium moisture (Me) & 0 & 0 & 0 & 0 & 0 & 0 & 0 & 0 \\
\hline n (drying constant exp[onnet) & 1.15 & 1.15 & 1.15 & 1.15 & 1.15 & 1.15 & 1.15 & 1.15 \\
\hline k (drying constant) & 0.09 & 0.09 & 0.09 & 0.09 & 0.09 & 0.09 & 0.09 & 0.09 \\
\hline Moisture ratio & 0.25 & 0.25 & 0.25 & 0.25 & 0.25 & 0.25 & 0.25 & 0.25 \\
\hline Drying time (min) & 11.10 & 11.10 & 11.10 & 11.10 & 11.10 & 11.10 & 11.10 & 11.10 \\
\hline Volume $\left(\mathrm{m}^{3}\right)$ & 2.11 & 1.59 & 1.06 & 0.53 & 0.32 & 0.21 & 0.11 & 0.05 \\
\hline Drying height for Zone $B(\mathrm{~m})$ & 2.79 & 2.54 & 2.22 & 1.76 & 1.49 & 1.30 & 1.03 & 0.82 \\
\hline
\end{tabular}




\begin{tabular}{|c|c|c|c|c|c|c|c|c|}
\hline Heating Zone for Drying & & & & & & & & \\
\hline Dimension a (mm) & 4 & 4 & 4 & 4 & 4 & 4 & 4 & 4 \\
\hline Dimension b (mm) & 20 & 20 & 20 & 20 & 20 & 20 & 20 & 20 \\
\hline Dimension c (mm) & 40 & 40 & 40 & 40 & 40 & 40 & 40 & 40 \\
\hline Volume of single wood chip $\left(\mathrm{mm}^{3}\right)$ & 3200 & 3200 & 3200 & 3200 & 3200 & 3200 & 3200 & 3200 \\
\hline Surface of a single wood chip $\left(\mathrm{mm}^{2}\right)$ & 2080 & 2080 & 2080 & 2080 & 2080 & 2080 & 2080 & 2080 \\
\hline $\mathrm{A} / \mathrm{V}(1 / \mathrm{m})$ & 650 & 650 & 650 & 650 & 650 & 650 & 650 & 650 \\
\hline Specific heat $\mathrm{C}\left(\mathrm{J} / \mathrm{kg}^{\circ} \mathrm{C}\right)$ & 2000 & 2000 & 2000 & 2000 & 2000 & 2000 & 2000 & 2000 \\
\hline Heat transfer coefficeint $\mathrm{HW} / \mathrm{m}^{2} \mathrm{C}$ & 10 & 10 & 10 & 10 & 10 & 10 & 10 & 10 \\
\hline Bulk denisty $\left(\mathrm{kg} / \mathrm{m}^{3}\right)$ & 166.7 & 166.7 & 166.7 & 166.7 & 166.7 & 166.7 & 166.7 & 166.7 \\
\hline Heating constant t $1 /(\min )$ & 1.17 & 1.17 & 1.17 & 1.17 & 1.17 & 1.17 & 1.17 & 1.17 \\
\hline$T$ & 100 & 100 & 100 & 100 & 100 & 100 & 100 & 100 \\
\hline$T \sim$ & 160 & 160 & 160 & 160 & 160 & 160 & 160 & 160 \\
\hline To & 20 & 20 & 20 & 20 & 20 & 20 & 20 & 20 \\
\hline Temp Ratio TR & 0.43 & 0.43 & 0.43 & 0.43 & 0.43 & 0.43 & 0.43 & 0.43 \\
\hline time (min) & 0.72 & 0.72 & 0.72 & 0.72 & 0.72 & 0.72 & 0.72 & 0.72 \\
\hline Volume flow $\left(\mathrm{m}^{3} / \mathrm{h}\right)$ & 10.20 & 7.65 & 5.10 & 2.55 & 1.53 & 1.02 & 0.51 & 0.26 \\
\hline Volume $\left(\mathrm{m}^{3}\right)$ & 0.12 & 0.09 & 0.06 & 0.03 & 0.02 & 0.01 & 0.01 & 0.00 \\
\hline Heating zone height & 0.16 & 0.15 & 0.13 & 0.10 & 0.09 & 0.08 & 0.06 & 0.05 \\
\hline
\end{tabular}


Heating Zone for Torrefaction Zone C

\begin{tabular}{|c|c|c|c|c|c|c|c|c|}
\hline & & & & & & & & \\
\hline Dimension a (mm) & 4 & 4 & 4 & 4 & 4 & 4 & 4 & 4 \\
\hline Dimension b (mm) & 20 & 20 & 20 & 20 & 20 & 20 & 20 & 20 \\
\hline Dimension c (mm) & 40 & 40 & 40 & 40 & 40 & 40 & 40 & 40 \\
\hline Volume of sinle wood chip $\left(\mathrm{mm}^{3}\right)$ & 3200 & 3200 & 3200 & 3200 & 3200 & 3200 & 3200 & 3200 \\
\hline Surface of a single wood chip $\left(\mathrm{mm}^{2}\right)$ & 2080 & 2080 & 2080 & 2080 & 2080 & 2080 & 2080 & 2080 \\
\hline AN $(1 / \mathrm{m})$ & 650 & 650 & 650 & 650 & 650 & 650 & 650 & 650 \\
\hline Specific heat $\mathrm{C}\left(\mathrm{J} / \mathrm{kg}^{\circ} \mathrm{C}\right)$ & 2000 & 2000 & 2000 & 2000 & 2000 & 2000 & 2000 & 2000 \\
\hline Bulk denisty $\left(\mathrm{kg} / \mathrm{m}^{3}\right)$ & 125.4 & 125.4 & 125.4 & 125.4 & 125.4 & 125.4 & 125.4 & 125.4 \\
\hline Heat transfer coefficeint $\mathrm{H}\left(\mathrm{W} / \mathrm{m}^{2} \mathrm{C}\right)$ & 15 & 15 & 15 & 15 & 15 & 15 & 15 & 15 \\
\hline Heating constant $t 1 /(\min )$ & 2.332 & 2.332 & 2.332 & 2.332 & 2.332 & 2.332 & 2.332 & 2.332 \\
\hline$T$ & 250 & 250 & 250 & 250 & 250 & 250 & 250 & 250 \\
\hline$T \sim$ & 300 & 300 & 300 & 300 & 300 & 300 & 300 & 300 \\
\hline To & 150 & 150 & 150 & 150 & 150 & 150 & 150 & 150 \\
\hline Temp Ratio TR & 0.33 & 0.33 & 0.33 & 0.33 & 0.33 & 0.33 & 0.33 & 0.33 \\
\hline time (min) & 0.47 & 0.47 & 0.47 & 0.47 & 0.47 & 0.47 & 0.47 & 0.47 \\
\hline Volume flow $\left(\mathrm{m}^{3} / \mathrm{h}\right)$ & 11.16 & 8.37 & 5.58 & 2.79 & 1.67 & 1.12 & 0.56 & 0.28 \\
\hline Volume $\left(\mathrm{m}^{3}\right)$ & 0.09 & 0.07 & 0.04 & 0.02 & 0.01 & 0.01 & 0.00 & 0.00 \\
\hline Heating zone height & 0.01 & 0.01 & 0.01 & 0.01 & 0.01 & 0.01 & 0.01 & 0.01 \\
\hline Total height (m) & 4.96 & 4.50 & 3.93 & 3.12 & 2.64 & 2.31 & 1.84 & 1.46 \\
\hline$L / D$ ratio & 5.0 & 5.0 & 5.0 & 5.0 & 5.1 & 5.1 & 5.1 & 5.1 \\
\hline \multicolumn{9}{|l|}{ Heat Required } \\
\hline Mass flow rate & 1000 & 750 & 500 & 250 & 150 & 100 & 50 & 25 \\
\hline Specific heat (J/(kg K) & 2880 & 2880 & 2880 & 2880 & 2880 & 2880 & 2880 & 2880 \\
\hline Temperature rise $\left({ }^{\circ} \mathrm{C}\right)$ & 230 & 230 & 230 & 230 & 230 & 230 & 230 & 230 \\
\hline Sensible heat required (kW) & 184 & 138 & 92 & 46 & 27.6 & 18.4 & 9.2 & 4.6 \\
\hline Latent heat to evaporate moisture (kW) & 415 & 311 & 207 & 104 & 62 & 41 & 21 & 10 \\
\hline Latent heat to remove volatiles (kW) & 156 & 117 & 78 & 39 & 23 & 16 & 8 & 4 \\
\hline Total heat required (kW) & 754 & 566 & 377 & 189 & 113 & 75 & 38 & 19 \\
\hline Total heat required (MBtu/hr) & 631 & 473 & 315 & 158 & 95 & 63 & 32 & 16 \\
\hline Assuming $5 \%$ heat losses & 0.05 & 0.05 & 0.05 & 0.05 & 0.05 & 0.05 & 0.05 & 0.05 \\
\hline Total heat required $(\mathrm{kW})$ & 792 & 594 & 396 & 198 & 119 & 79 & 40 & 20 \\
\hline Total heat required (Btu/hr) & 662 & 497 & 331 & 166 & 99 & 66 & 33 & 17 \\
\hline Heat content of volatiles (kW) & 278 & 208 & 139 & 69 & 42 & 28 & 14 & 7 \\
\hline
\end{tabular}


Nitrogen Gas Required (Mass Flow)

\begin{tabular}{|c|c|c|c|c|c|c|c|c|}
\hline Temperature rise & 280.0 & 280.0 & 280.0 & 280.0 & 280.0 & 280.0 & 280.0 & 280.0 \\
\hline Mass flow of nitrogen $(\mathrm{kg} / \mathrm{s})$ & 1.83 & 1.37 & 0.91 & 0.46 & 0.27 & 0.18 & 0.09 & 0.05 \\
\hline Mass flow of nitrogen with $30 \%$ of heat load (kg/s) & 0.55 & 0.41 & 0.27 & 0.14 & 0.08 & 0.05 & 0.03 & 0.01 \\
\hline Volume flow rate of nitrogen $\left(\mathrm{m}^{3} / \mathrm{s}\right)$ & 0.7 & 0.5 & 0.4 & 0.2 & 0.1 & 0.1 & 0.0 & 0.0 \\
\hline Volume flow rate of nitrogen with half heat load $\left(\mathrm{m}^{3} / \mathrm{min}\right)$ & 43.9 & 32.9 & 21.9 & 11.0 & 6.6 & 4.4 & 2.2 & 1.1 \\
\hline Volune flow rate of nitrogen $\left(\mathrm{ft}^{3} / \mathrm{min}\right)$ & 1549.0 & 1161.8 & 774.5 & 387.3 & 232.4 & 154.9 & 77.5 & 38.7 \\
\hline \multicolumn{9}{|l|}{ Pressure Drop and Blower Capactiy } \\
\hline Bed depth $(m)$ & 4.96 & 4.50 & 3.93 & 3.12 & 2.64 & 2.31 & 1.84 & 1.46 \\
\hline Area $\left(m^{2}\right)$ & 0.76 & 0.62 & 0.48 & 0.30 & 0.21 & 0.16 & 0.10 & 0.06 \\
\hline$Q=F l o w$ rate per unit area $\left(\mathrm{m}^{3} / \mathrm{s}-\mathrm{m}^{2}\right)$ & 0.96 & 0.88 & 0.77 & 0.61 & 0.51 & 0.45 & 0.36 & 0.28 \\
\hline$Q=$ Flow rate per unit area $\left(\mathrm{m}^{3} / \mathrm{s}-\mathrm{m}^{2}\right)$ (with half heat laod) & 0.48 & 0.44 & 0.38 & 0.30 & 0.26 & 0.22 & 0.18 & 0.14 \\
\hline$b=$ constant $\left(m^{2}-s / m^{3}\right)$ & 325 & 325 & 325 & 325 & 325 & 325 & 325 & 325 \\
\hline$a=$ constant $\left(P a-s^{2} / m^{3}\right)$ & 10400 & 10400 & 10400 & 10400 & 10400 & 10400 & 10400 & 10400 \\
\hline Pressure drop (Pa) & 8326 & 6366 & 4348 & 2270 & 1414 & 973 & 513 & 271 \\
\hline Power (watt)(j/sec)(N.m/s) & 6087 & 3491 & 1589 & 415 & 155 & 71 & 19 & 5 \\
\hline Blower size (W/0.5) & 12174 & 6981 & 3179 & 830 & 310 & 142 & 37 & 10 \\
\hline
\end{tabular}




\section{CONCLUSIONS}

1. Torrefied biomass in general defines a group of products resulting from the partially controlled and isothermal pyrolysis of biomass occurring at a temperature range of 200$300^{\circ} \mathrm{C}$.

2. The common torrefaction reactions include (a) devolatilization and carbonization of hemicelluloses and (b) depolymerization and devolatilization of lignin and cellulose.

3. Torrefaction reduces the variability in biomass feedstocks and helps to develop a uniform feedstock with consistent physical, chemical, and biochemical composition.

4. Torrefaction of biomass improves:

- $\quad$ Physical properties like grindability and pelletability, thereby increasing energy density

- Ultimate and proximate composition by increasing the carbon content and calorific value and decreasing the moisture and oxygen content

- $\quad$ Biochemical composition by decomposing the hemicelluloses and softening the lignin, resulting in better binding during pelletization.

5. Densification of torrefied material at $225^{\circ} \mathrm{C}$ reduces the energy consumption and increases the throughput by a factor of two.

6. During torrefaction, the biomass loses most of the low energy content of the material (a) solids, which include original sugar structures and other newly formed polymeric structures; (b) liquids, which are condensables like water organics and lipids, and (c) gases like $\mathrm{CO}$ and $\mathrm{CO}_{2}$.

7. Off-gas emissions from a torrefied biomass during storage are less when compared to raw biomass.

8. Torrefied biomass, being hydrophobic, does not absorb moisture from the environment and remains stable for long storage times.

9. Torrefied biomass has a wider range of application, especially when densified and used in power generation plants along with coal.

10. The MS Excel@ design worksheets, included in this document, can be useful for understanding the amount of heat required, L/D ratios, and gas requirements for a model torrefaction system.

\section{ACKNOWLEDGEMENTS}

This work is supported by the U.S. Department of Energy, under DOE Idaho Operations Office Contract DE-AC07-05ID14517. Accordingly, The U. S. Government retains and the publisher, by accepting the article for publication, acknowledges that the U. S. Government retains a nonexclusive, paid-up, irrevocable, world-wide license to publish or reproduce the published form of this manuscript, or allow others to do so, for U. S. Government purposes. 


\section{U.S. DEPARTMENT OF ENERGY DISCLAIMER}

This information was prepared as an account of work sponsored by an agency of the U.S. Government. Neither the U.S. Government nor any agency thereof, nor any of their employees, makes any warranty, express or implied, or assumes any legal liability or responsibility for the accuracy, completeness, or usefulness of any information, apparatus, product, or process disclosed, or represents that is use would not infringe privately owned rights. References herein to any specific commercial product, process, or service by trade name, trademark, manufacturer, or otherwise, does not necessarily constitute or imply its endorsement, recommendation, or favoring by the U.S. Government or any agency thereof. The views and opinions of authors expressed herein do not necessarily state or reflect those of the U.S. Government or any agency thereof.

\section{References}

Arias, B. R., C.G. Pevida, J.D. Fermoso, M.G. Plaza, F.G. Rubiera, and J. J. Pis Martinez. 2008. Influence of torrefaction on the grindability and reactivity of woody biomass. Fuel Processing Technology, 89(2), 169-175.

Bergman, P.C.A. 2005. Combined torrefaction and pelletisation: The TOP Process. ECN-C--05073.

Bergman, P.C.A., and J.H.A. Kiel. 2005. Torrefaction for biomass upgrading. Published at 14th European Biomass Conference \& Exhibition, Paris, France, October 17-21, 2005.

Bergman, P.C.A., A.R. Boersma, J.H.A. Kiel, M.J. Prins, K.J. Ptasinski, F.J.J.G. Janssen. 2005. Torrefied biomass for entrained-flow gasification of biomass. Report ECN-C--05-026.

Bergman, P.C.A., A.R. Boersma, R.W.H. Zwart, and J.H.A. Kiel. 2005a. Torrefaction for biomass co-firing in existing coal-fired power stations, ECN-C--05-013.

Bourgois, J. and R. Guyonnet.1988. Characterization and analysis of torrefied wood. Wood Science and Technology, 22 (2), 143-155.

Bourgois, J. P. and J. Doat. 1984. Torrefied wood from temperate and tropical species: advantages and prospects. In Bioenergy 84, Goteborg, Sweden, June 15-21, 1984, Elsevier Applied Science Publishers, 153-159.

Bridgeman, T.G., L. I. Darvell, B. Gudka, E. M Fisher, J. M Jones, D, Waldron, and A. Williams.2011. Milling and combustion properties of torrefied biomass, a potential co-firing fuel, Cofiring Biomass with Coal Workshop, Presentations given at Drax Power Station, 2526 January 2011.

Bridgeman, T, G., J.M. Jones, I .Shield, and P.T .Williams. 2008. Torrefaction of reed canary grass, wheat straw and willow to enhance solid fuel qualities and combustion properties. Fuel, 87 (6), 844-856.

Demirbas, A. 2009. Pyrolysis mechanisms of biomass materials. Energy Sources, Part A: Recovery, Utilization, and Environmental Effects, 31 (13), 1186-1193.

Deng. J., G. Wang, J .Kuang, Y .Zhang, and Y. Luo. 2009. Pretreatment of agricultural residues for co-gasification via torrefaction. Journal of Analytical and Applied Pyrolysis. 86 (2), 331337. 
Dufour, A., P. Girods, E. Masson, S. Normand, Y. Rogaume, and A. Zoulalian. 2007. Comparison of two methods of measuring wood pyrolysis tar. Journal of Chromatography A, 1164 (1-2), 240-247.

Esteban, L.S., and J.E. Carrasco. 2006. Evaluation of different strategies for pulverization of forest biomasses. Powder Technology 166 (3), 139-151.

Fonseca, F. F., C.A. Luengo, G. Bezzon, and P. B. Soler. 1998. Bench unit for biomass residues torrefaction. Proceedings of Conference on Biomass for Energy and Industry, Würzburg, Germany, June 8-11, 1998.

Hakkou, M., M. Pétrissans, P. Gérardin, and A. Zoulalian. 2006. Investigation of the reasons for fungal durability of heat-treated beech wood. Polymer Degradation and Stability, 91 (2), 393-397.

I.E.A. Bioenergy, 2010.Task 34 Leader: Doug Elliott, Pyrolysis of biomass, www.pyne.co.uk, published 2010, Web page visited June.

Kavalov, B., and S.D. Peteves. 2005. Status and perspectives of biomass-to-liquid fuels in the European Union. European Commission-DG JRC, Institute for Energy, Petten, The Netherlands, 92-894-9784-X.

Kiel, J. 2007. Torrefaction for biomass upgrading into commodity fuels. IEA Bioenergy Task 32 workshop on "Fuel storage, Handling and Preparation and System Analysis for Biomass Combustion Technologies, Berlin, May 7.

Koukios, E.G. 1993. Progress in thermochemical, solid state refining of biofuels: from research to commercialization. Advanced Thermochemical Biomass Conversion, 2.

Kuang, X., J.S. Tumuluru, X.T. Bi, C.J. Lim, S. Sokhansanj, and S. Melin. 2009. Rate and peak concentrations of off-gas emissions in stored wood pellets-sensitivities to temperature, relative humidity, and headspace volume. Annals of Occupational Hygiene 53 (8), 789-796.

Lehtikangas, P. 1999. Quality properties of fuel pellets from forest biomass, Licentiate Thesis, University of Agricultural Sciences, Uppsala, Sweden.

Lipinsky, E.S., J.R .Arcate, and T.B. Reed. 2002. Enhanced wood fuels via torrefaction. Fuel Chemistry Division Preprints, 47 (1), 408-410.

Mani, S, 2009. Integrating biomass torrefaction with thermo-chemical conversion processes. Proceedings of the 2009 AIChE Annual Meeting, Nashville, Tennessee, Nov 8-13, 2009.

Mani, S., L.G. Tabil, and S Sokhansanj. 2004. Grinding performance and physical properties of wheat and barley straws, corn stover and switchgrass. Biomass and Bioenergy 27(4), 339352.

Mohan, D., C.U. Pittman, and P.H. Steele. 2006. Pyrolysis of wood/biomass for bio-oil: A critical review. Energy \& Fuels, 20 (3), 848-889.

Murphy, J.D., and K .McCarthy. 2005. Ethanol production from energy crops and wastes for use as a transport fuel in Ireland. Applied Energy, 82 (2), 148-166.

Pach, M., R, Zanzi, and E. Björnbom. 2002. Torrefied biomass a substitute for wood and charcoal. In Sixth Asia-Pacific International Symposium on Combustion and Energy Utilization, Kuala Lumpur, May 20-22, 2002.

Pastorova, I., P.W. Arisz, and J.J. Boon. 1993. Preservation of d-glucose oligosaccharides in cellulose chars. Carbohydrate Research, 248, 151-165. 
Pentananunt, R., A.N.M. Mizanur Rahman, and S.C. Bhattacharya. 1990. Upgrading of biomass by means of torrefaction. Energy, 15(12), 1175-1179.

Phanphanich, M., and S. Mani. 2011. Impact of torrefaction on the grindability and fuel characteristics of forest biomass. Bioresource Technology 102, 1246-1253.

Prins, M. J. 2005. Thermodynamic analysis of biomass gasification and torrefaction. Thesis submitted to Eindhoven: Technische Universiteit Eindhoven, 2005.

Prins, M.J., K.J. Ptasinski, and F.J.J.G. Janssen. 2006. Torrefaction of wood: Part 1: Weight loss kinetics. Journal of Analytical and Applied Pyrolysis, 77 (1), 28-34.

Prins, M.J., K.J. Ptasinski, and F.J.J.G. Janssen. 2006a. More efficient biomass gasification via torrefaction. Energy 31(15), 3458-3470.

Prins, M.J., K.J Ptasinski, and F.J.J.G.Janssen. 2006b. Torrefaction of wood: Part 2: Analysis of products. Journal of Analytical and Applied Pyrolysis, 77(1) 35-40.

Reed, T., and B. Bryant. 1978. Densified biomass a new form of solid fuel. Solar Energy Research Institute, US Department of Energy, Division of Solar Technology.

Rodrigues, T. O., and Rousset, P. L. A. 2009. Effects of torrefaction on energy properties of Eucalyptus Grandis wood. Cerne, 15 (4), 446-452.

Sadaka, S., and S, Negi. 2009. Improvements of biomass physical and thermochemical characteristics via torrefaction process. Environmental Progress \& Sustainable Energy, 28(3), 427-434.

Shaw, M. 2008. Feedstock and process variables influencing biomass densification, Ph.D. Thesis, University of Saskatchewan, Saskatoon, Saskatchewan, Canada.

Sokhansanj, S., J.H. Peng, X.T. Bi, C. J. Lim, L,Wang, P. S Lam, J.P Hoi, S. Melin, J.S. Tumuluru, C.T. Wright. 2010. Optimum torrefaction and pelletization of biomass feedstock. Symposium on Thermal and Catalytic Sciences for Biofuels and Biobased Products. lowa state University, September, 21-23.

Solo, M.L. 1965. Mattalorest, Aikakawsh, 37, 127.

J.S. Tumuluru, X, Kuang S, Sokhansanj C.J. Lim, X.T. Bi, L, Anthony, S.Melin. 2010. Development of laboratory studies on the off-gassing of wood pellets. Canadian Biosystems Engineering, 52: 8.1-8.9.

United Nations (UN). 1998. Kyoto protocol to the United Nations framework convention on climate change.

P.J. Van Soest. 1964. Symposium on nutrition and forage and pastures: new chemical procedures for evaluating forages. Journal of Animal Science, 23, 838-845.

R.H. White. and M.A. Dietenberger. 2001. Wood products: Thermal degradation and fire. K.H. Jürgen Buschow., R.W. Cahn, M.C. Flemings, B. Ilschner, E.J. Kramer, S. Mahajan, and P. Veyssière (eds.), The Encyclopedia of Materials: Science and Technology, Elsevier, Ltd.: Amsterdam, pp. 9712-9716.

Wooten, J.B., B. Crosby, and M.R. Hajaligol. 2000. Evaluation of cellulose char structure monitored by CCP MAS NMR. Fuel Chemistry Division Preprints, 46, 191-193.

Yan, W., J.T. Hastings, T.C. Acharjee, C.J .Coronella, and V.R. Váasquez. 2010. Mass and energy balances of wet torrefaction of lignocellulosic biomass. Energy Fuels (In press). 
Zanzi, R., D.T. Ferro, A. Torres, P.B. Soler, and E.Bjornbom. 2002. Biomass torrefaction. In The 6th Asia-Pacific International Symposium on Combustion and Energy Utilization, Kuala Lumpur, May 20-22, 2002. 